\title{
APPENDIX 1: EVIDENCE REVIEW ON OCCUPATIONAL EXPOSURE OF SWINE AND POULTRY WORKERS
}

Please note: The provision of recommendations regarding immunization of swine workers as a means to protect swine herds is not within the scope of $\mathrm{NACl}$. For animal health concerns, the reader should refer to appropriate animal health resources.

\section{Preamble}

The National Advisory Committee on Immunization (NACl) provides the Public Health Agency of Canada (hereafter referred to as the Agency) with ongoing and timely medical, scientific and public heath advice relating to immunization. The Agency acknowledges that the advice and recommendations set out in this statement are based upon the best currently available scientific knowledge and is disseminating this document for information purposes. People administering the vaccine should also be aware of the contents of the relevant product monograph(s). $\mathrm{NACl}$ recommendations for use and other information set out herein may differ from that set out in the product monograph(s). Manufacturer(s) have sought approval of the vaccine(s) and provided evidence as to its safety and efficacy only when it is used in accordance with the product monographs. $\mathrm{NACl}$ members and liaison members conduct themselves within the context of the Public Health Agency of Canada's Policy on Conflict of Interest, including yearly declaration of potential conflict of interest.

NACI Members: Dr. B. Warshawsky (Chairperson), Dr. N. Crowcroft, Dr. I. Gemmill, Dr. B. Henry, Dr. D. Kumar, Dr. S. McNeil, Dr. C. Quach-Thanh, Dr. M. Salvadori, Dr. B. Seifert, Dr. N. Sicard, Dr. W. Vaudry, Dr. R. Warrington.

Liaison Representatives: Dr. S. Deeks (Canadian Public Health Association), Dr. A. Mawle (Centres for Disease Control and Prevention, U.S.), Dr. D. Moore (Canadian Paediatric Society), Dr. H. Morrison (Council of Chief Medical Officers of Health), Dr. A. Opavsky (Association of Medical Microbiology and Infectious Disease Canada), Dr. A. Pham-Huy (Canadian Association for Immunization Research and Evaluation), Dr. S. Rechner (College of Family Physicians of Canada), Dr. V. Senikas (Society of Obstetricians and Gynaecologists of Canada).

Ex-Officio Representatives: Dr. M. Carew (First Nations and Inuit Health Branch, Health Canada), Dr. (LCol) P. Egan (Department of National Defence), Dr. A. Klein (Biologics and Genetic Therapies Directorate, Health Canada), Dr. B. Law (Centre for Immunization and Respiratory Infectious Diseases, PHAC), Dr. C. Légaré (Marketed Biologicals, Biotechnology and Natural Health Products Bureau, Health Canada), Dr. B. Raymond (Centre for Immunization and Respiratory Infectious Diseases, PHAC/Canadian Immunization Committee), Ms. M. St-Laurent (Surveillance and Outbreak Response Division, PHAC).

NACl gratefully acknowledges the contribution of: Dr. O. Baclic, Dr. B. Cholin, Dr. S. Desai, Dr. S. Halperin, Dr. P. Huston, Dr. J. Langley, Dr. A. McGeer, and Dr. P. Van Buynder.

Animal Health Experts: Dr. R. Arora (Canadian Food Inspection Agency), Dr. J. Copps (National Centre for Foreign Animal Diseases), Dr. J. Dhanda (Canadian Food Inspection Agency), Dr. A. Harchaoui (Canadian Food Inspection Agency), Dr. J. Keenliside (Alberta Agriculture and Rural Development), and Dr. B. Radke (British Columbia Centre for Disease Control). 


\section{Table of Contents}

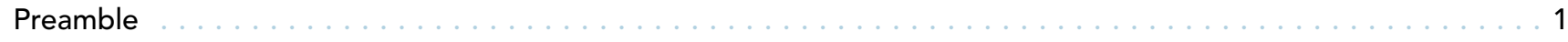

I. Executive Summary . . . . . . . . . . . . . . . . . . . . . . .

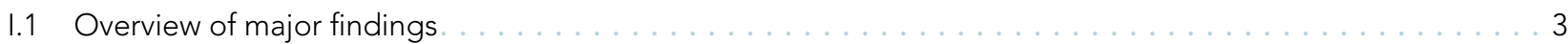

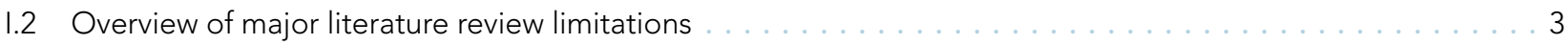

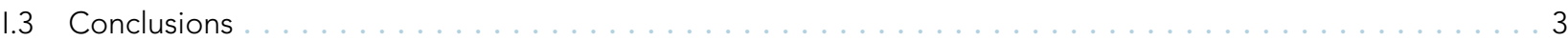

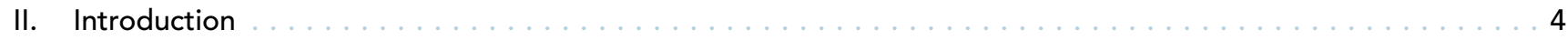

II.1 Epidemiology of animal-origin influenza viruses $\ldots \ldots \ldots \ldots \ldots$

II.2 Pandemic risk . . . . . . . . . . . . . . . . . . . . . . . . . . .

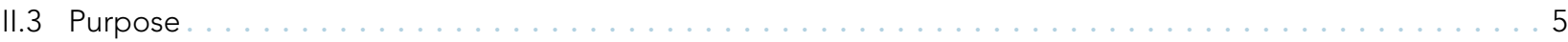

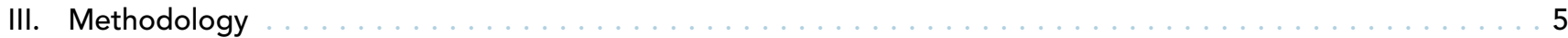

III.1 CADTH Rapid Response Report . . . . . . . . . . . . . . . . . . . . . . . . . . . 5

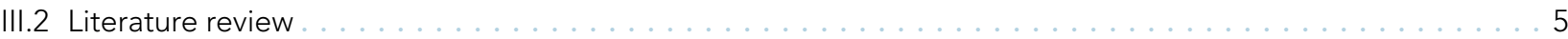

III.3 IWG Meeting with Animal Health Experts . . . . . . . . . . . . . . . . . .

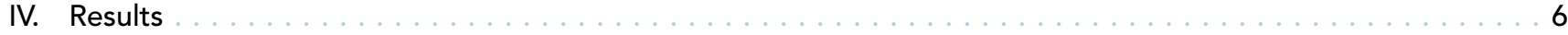

IV.1 CADTH Rapid Response Report . . . . . . . . . . . . . . . . . . . . 6

IV.2 PHIWG Literature Review . . . . . . . . . . . . . . . . . . . . . .

IV.2.1 Avian influenza virus in individuals occupationally exposed to poultry or wild birds. ........6

IV.2.2 Secondary transmission of AIV . . . . . . . . . . . . . . . . . . . .

IV.2.3 Swine influenza virus in individuals occupationally exposed to swine $\ldots \ldots \ldots$. . . . . . . .

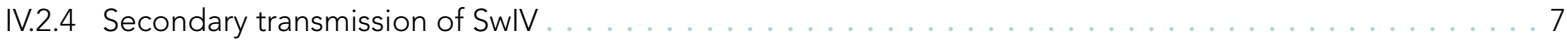

IV.2.5 Influenza vaccination among all occupationally exposed individuals . . . . . . . . . . . 8

IV.2.6 Existing influenza vaccination recommendations for occupationally exposed individuals ........8

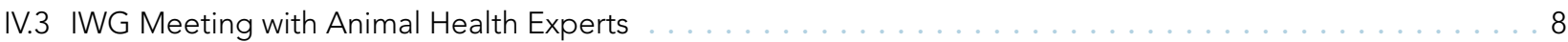

V. Discussion . . . . . . . . . . . . . . . . . . . . . . . . . . .

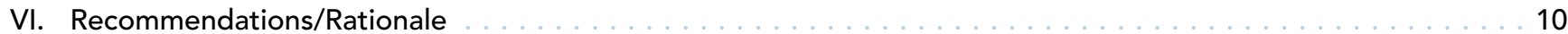

VI.1 Poultry workers . . . . . . . . . . . . . . . . . . . . . . . . . . . . 10

VI.2 Swine Workers . . . . . . . . . . . . . . . . . . . . . . . . . 11

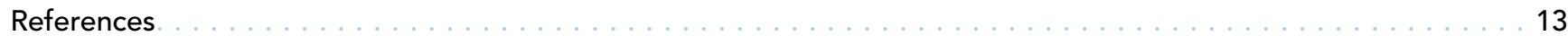

Appendix A: Summary of Evidence for NACI Recommendation . . . . . . . . . . . . . . 17

Appendix B: National seasonal influenza vaccination recommendations for workers occupationally exposed to animals 


\section{Executive Summary}

In mid-2012, in response to the emergence of several swine variant influenza strains in humans in the United States of America (USA) (H3N2v, H1N1v, H1N2v) and in Canada (H1N1v) the Public Health Agency of Canada (PHAC) requested the Influenza Working Group (IWG) of the National Advisory Committee on Immunization (NACl) to consider a recommendation for immunization of individuals with occupational exposure to swine and poultry. In Canada, NACI's process for development of influenza immunization recommendations takes into consideration a broad range of available studies and data to make evidence-based recommendations in the evaluation of the safety and efficacy of vaccines for humans. Professional judgment, clinical experience and an overall analysis of risk also influences recommendations. For animal health concerns, the reader should refer to appropriate animal health resources.

To inform this discussion, PHAC and NACI IWG undertook various methods of exploring the question including scientific evidence, best practices, and expert opinion. This report outlines the process, studies, and data used by $\mathrm{NACl}$ to develop its recommendation for seasonal vaccination of swine and poultry workers. The evidence includes:

- A rapid review conducted by the Canadian Agency for Drugs and Technologies in Health titled "Influenza Vaccination for Prevention of Cross-species Infection: A Review of the Clinical Evidence"

- A literature review was conducted to identify the prevalence and risk of cross-species transmission of animal influenza $A$.

- A meeting with animal health experts to understand current vaccination practices of swine and poultry workers, the biosecurity measures used in the industry, and the risk of cross-species influenza transmission.

\section{I.1 OVERVIEW OF MAJOR FINDINGS}

- No studies were identified that examined the effectiveness of vaccination of swine and poultry workers on genetic reassortment of influenza virus.

- Transmission of avian or swine influenza from animal populations to occupationally exposed humans occurs, but not frequently.
- Occupationally exposed workers are more likely to be seropositive for avian or swine influenza than unexposed individuals.

- The potential for limited human-to-human transmission exists from infected workers to unexposed household members.

- There is a wide range of seasonal influenza vaccination rates among workers.

- Most Canadian swine veterinarians are members of professional associations that already have position statements in favour of seasonal vaccination, and most veterinarians are aware of these recommendations.

- Canadian farms have strict bio-security measures that are their major means of avian/swine influenza prevention.

\section{I.2 OVERVIEW OF MAJOR LITERATURE REVIEW LIMITATIONS}

- Large amount of heterogeneity between studies impacted comparability

- Lack of standard testing protocols for seroresponse to non-human, non-H5N1 strains

- Studies use different titre cut-offs to identify a positive response

- Potential for waning immunity and/or cross-protection to impact detection

- Cross-reactivity between swine, avian and human influenza viruses

- Many of the studies were cross-sectional seroprevalence surveys

- Prevalence of avian or swine influenza viruses in the animal populations or the region was usually not known or its presence was not confirmed

- Some studies established control groups, but there were comparability issues

\section{I.3 CONCLUSIONS}

After discussing the available body of evidence, $\mathrm{NACl}$ unanimously decided on the following recommendations:

- "NACl concludes that there is insufficient evidence at this time to specifically recommend routine influenza immunization for swine workers (NACl recommendation grade l); however $\mathrm{NACl}$ encourages influenza vaccine for all Canadians age 6 months and older." 
- " $\mathrm{NACl}$ continues to recommend immunization against seasonal influenza for people in direct contact during culling operations involving poultry infected with avian influenza ( $\mathrm{NACl}$ recommendation grade l); however $\mathrm{NACl}$ encourages influenza vaccine for all Canadians age six months and older".

\section{Introduction}

The genetic reassortment of influenza A viruses from different animal species is thought to be a mechanism for the development of influenza viruses with pandemic potential. Human influenzas and influenza viruses of avian and swine origin mostly circulate exclusively within their respective species. However, influenza viruses possess the ability to infect and potentially transmit themselves in species other than their native host. Influenza A viruses are categorized based on combinations of the two surface proteins hemaglutinin and neuraminidase. In a statistical analysis of 3,874 full-length neuraminidase sequences (N1-N9), Yan et al. (2010)' found that there is greater intraspecies variation than inter-species variation in some host species. While a number of virus subtypes do not appear to be transmissible between species, some subtypes have a weak barrier, and some have virtually no barrier between species, in nature and in laboratory experiments.

\section{II.1 EPIDEMIOLOGY OF ANIMAL- ORIGIN INFLUENZA VIRUSES}

Humans working with live or dead animals that are also reservoirs for influenza, including, but not limited to, poultry and swine, are presumably at higher risk for infecting and being infected by the animals they work with due to their high degree of interaction. The role of animal-origin influenza viruses in causing human illness has been recognized for some time; however, it is unclear how frequently animal influenza viruses are transmitted to humans, or vice versa. The majority of existing surveillance systems are not set up to detect asymptomatic or mild illness in humans caused by human or animal influenzas. As well, swine influenza is not federally reportable in Canada and there is no national human surveillance systems set up to specifically identify swine origin influenza in humans. Despite this, routine testing done in animals and humans does identify emergent influenza strains and some have generated significant interest.
These recommendations are reflected in the Statement on Seasonal Influenza Vaccine for 2013-2014.

Avian influenza has economic and health implications. Notifiable Avian Influenza (NAI) are identified as all H5 and $\mathrm{H} 7$ and any highly pathogenic avian influenza (HPAl) viruses. Low pathogenicity avian influenza (LPAI) viruses are associated with mild or no apparent disease in poultry. HPAl viruses can cause severe illness and high mortality in poultry flocks. Extensive culling measures are usually taken to control NAl viruses (NAIVs), which can be devastating to poultry operations. Currently, the most prolific AIV is highly pathogenic H5N1. Since its emergence in 1997, H5N1 has caused 371 deaths out of 622 confirmed human cases² (as of March 12, 2013) and has been heavily monitored as an influenza strain with pandemic potential. To date, however, it has yet to develop the capacity for efficient human-tohuman transmission, although it continues to have a high case fatality rate when contracted by humans.

Surveillance of NAIV is fairly well established. The Canadian Notifiable Avian Influenza Surveillance System (CanNAISS) is a joint initiative between government, industry and farmers to prevent, detect, and eliminate $\mathrm{H} 5$ and H7 AIV subtypes. CanNAISS meets the notifiable avian influenza guidelines established by the World Organization for Animal Health (OIE) and trade requirements from the European Union. ${ }^{3}$

Unlike AIVs, swine influenza viruses (SwIVs) generally cause few deaths in pigs, but can cause high levels of illness in pig herds. Swine are of particular interest in interspecies transmission of influenza because they possess receptors in the respiratory tract that allow them to contract both human and avian influenza viruses. Transmission of influenza between swine and humans is known to occur, as is transmission from poultry to swine. Swine have historically been considered the ideal mixing vessel for the production of novel viruses; however, recent research reveals that based on receptors alone, swine and humans are equally likely to act as mixing vessels for viral reassortment. 4,5 
In Canada, there are no federal surveillance programs for the detection of influenza in swine, and existing provincial and territorial surveillance programs may vary. A voluntary swine influenza surveillance program was initiated in the US in 2008, operated through the United States Department of Agriculture in collaboration with states and industry. Between October 1, 2010 through July 31, 2012, the program tested 12,662 samples taken from 3,766 swine diagnostic lab submissions (multiple samples from each submission), and found that 1,488 were positive for influenza $A$ infections. ${ }^{6}$

\section{II.2 PANDEMIC RISK}

An influenza pandemic is an unpredictable but recurring event that can have a significant impact on the population. ${ }^{7}$ It occurs when a novel influenza virus, transmissible to and amongst humans, and against which humans have little to no immunologic protection, spreads widely across the world. Since the $16^{\text {th }}$ century, pandemics have occurred at intervals of $10-50$ years. ${ }^{8}$ There is no way to predict when a novel influenza strain will emerge and become a pandemic

\section{Methodology}

\section{III.1 CADTH RAPID RESPONSE REPORT}

In February 2012, PHAC requested that the Canadian Agency for Drugs and Technologies in Health (CADTH) review the clinical evidence regarding the effectiveness of immunization of animal workers to reduce the risk of cross-species influenza infection in humans, and the risk of co-infection with human and animal influenza. There were two research questions:

1. What is the clinical evidence regarding the effectiveness of immunization of animal workers to reduce the risk of cross-species influenza infection in humans?

2. What is the clinical evidence regarding the effectiveness of immunization of animal workers to reduce the risk of co-infection with human and animal influenza?

A limited literature search was conducted using PubMed, The Cochrane Library, University of York Centre for Reviews and Dissemination databases, Canadian and major international health technology agencies, as well as a focused Internet search. All study types were considered, and the search was limited to studies published in the English language between January 1, 2007 and January 11, 2012. For a more detailed methodology, please refer to the report. ${ }^{10}$ concern, and how severe it may be. The H1N1 influenza strain in the 2009 pandemic was antigenically similar to H1N1 viruses circulating among North America swine, and distinct from seasonal human $\mathrm{H} 1 \mathrm{~N} 1$ viruses; its genome comprised a reassortment of genes of avian, human and swine origin influenza A viruses. ${ }^{9}$ This highlights the role genetic reassortment plays in the evolution of pandemic influenza strains.

\section{II.3 PURPOSE}

The objective of this review is to assess the body of evidence around the risk and prevalence of cross-species influenza transmission to and from humans. This review includes a Rapid Response Report from the Canadian Agency for Drugs and Technologies in Health, a literature review on cross-species influenza transmission, and a meeting with members of the Avian Flu Task Group from the joint committee of the Chief Medical Officers of Health, as well as the Chief Veterinary Officers.

\section{III.2 LITERATURE REVIEW}

Two searches were conducted in each of the following four databases: Medline, Embase, Global Health, and Agricola, for literature published in the English language up until July 3, 2012. The first search focused on swine or avian influenza infection in agricultural or farm workers who work with livestock, and the second search focused on crossspecies influenza infection. A total of 273 and 1163 articles were retrieved from the first and second searches respectively. The searches were kept broad to assess the size of the body of evidence that exists on the subject. Following this assessment, additional criteria were applied to narrow the scope of the review. The inclusion criteria for articles of interest were for those that involved crossspecies influenza infection to or from humans who raise and/or work with live or dead animals. Articles were excluded if they were not conducting primary research, involved experimental influenza infection, conducted analysis for influenza strains native to the study population (e.g. avian influenza in poultry, human influenza in humans), or were published prior to the year 1997. Please refer to Appendix A for the evidence tables.

A rapid review limited to the English and French language was also conducted to determine which countries currently make an explicit recommendation for animal workers to receive the seasonal influenza vaccination (Appendix B). 


\section{III.3 IWG MEETING WITH ANIMAL HEALTH EXPERTS}

The Influenza Working Group (IWG) held an ad hoc meeting in December 2012 in order to discuss the current vaccination practices of swine and poultry workers, the biosecurity

\section{Results}

\section{IV.1 CADTH RAPID RESPONSE REPORT}

The literature search yielded a total of 219 citations, 215 of which were excluded after reviewing the titles and citations. Four potentially relevant articles under-went a full text review, as did an article identified in the grey literature. None of these five articles met the inclusion criteria. Some studies examined the effect of influenza vaccines in the general population, healthy volunteers, children, older people, or focused on health care workers, but none focused on animal workers.

\section{IV.2 PHIWG LITERATURE REVIEW}

A total of 44 articles meeting the inclusion and exclusion criteria were selected for the review. Thirty-one articles assessed the seroprevalence of AIV in individuals occupationally exposed to poultry flocks or wild birds, and 13 articles assessed SwIV in individuals occupationally exposed to swine. A broad range of individuals with the potential to be occupationally exposed to AIV or SwIV were surveyed including backyard farmers, farmers or workers in commercial farm operations, cullers/ slaughterers, meat processors, veterinarians, laboratory analysts, researchers, government workers, ${ }^{11}$ firefighters, ${ }^{11}$ migratory bird handlers, and bird banders. In both avian and swine exposed individuals, immunological indications of cross-species infection were not detected at high frequencies. Low levels of antibody response in the study population to an animal influenza were detected in a majority of the studies, although some may have been the result of cross-reactivity to exposure to human influenzas. A small number of studies also included an assessment of household members of individuals with confirmed AIV or SwIV as study participants or as control groups. measures used in the industry, and risk of cross-species influenza transmission with members of the Avian Flu Task Group from the joint committee of the Chief Medical Officers of Health, as well as the Chief Veterinary Officers. Please refer to the discussion for further information.

\section{IV.2.1 Avian influenza virus in individuals occupationally exposed to poultry or wild birds}

Of the 31 articles assessing the seroprevalence of AIV in humans, eight assessed seroprevalence of AIV in cullers, slaughterers or individuals collecting dead birds. ${ }^{11-17}$ Eighteen articles assessed commercial poultry workers, seven articles assessed non-commercial poultry workers (i.e. backyard farmers), and four studies assessed other workers including bird banders, ${ }^{18}$ handlers of migratory birds, ${ }^{19}$ firefighters, ${ }^{11}$ and government workers ${ }^{11}$ involving in culling.

Of the 18 articles involving commercial poultry workers, eight articles considered an individual seropositive if antibody titres were at least $\geq 1: 10$. Another eight articles characterized seropositivity with titers at least $\geq 1: 80$. One article had undisclosed seropositivity conditions, and another article collected information on symptoms only. Noting the difference in use of titre thresholds is important as at present, a titre of $\geq 1: 80$ is the recommended threshold for assessing potential H5N1 infection. No other recommendations exist for other avian influenza strains, although some articles used the H5N1 recommendations as a guideline for their laboratory tests. A few of the other studies used a threshold of $\geq 1: 80$, but these were grouped with the 1:80 studies for comparative purposes.

Overall, the seroprevalence of AIV was typically low $(<1 \%$ of participants), but some serological activity was detected in a majority of the studies. Two articles using an antibody titre threshold $\leq 1: 80$ did not find any evidence of serological activity. Four articles using a threshold of $\geq 1: 80$ reported having participants with low levels of serological activity, but none met the conditions for seropositivity. 
In the small number of studies assessing both poultry workers and cullers, cullers constituted the majority of seropositive cases. Alizadeh et al (2009) found seropositivity for AIV in slaughter-house workers to be 2.09 times higher than in poultry workers ( $51.6 \%$ vs. $24.6 \%)$ among the 48/127 workers who tested positive for H9N2 (titres $\geq 1: 20$ ).12 During an outbreak of H5N1 in South Korea, the $9 / 2512$ positive cases (titres $\geq 1: 80$ ) were all cullers. 15 In a study by Schultsz et al (2009), 3/317 cullers involved in culling for more than one year presented with microneutralization (MN) titres of 1:20, 1:40 and 1:200. None of the 183 poultry workers showed positive titre against H5N1.17 However, a study in rural Cambodia, done by Vong et al (2006), identified slaughtering chickens as a non-significant risk factor for seropositivity after controlling for exposures such as cleaning up cages/ stalls, handling live poultry, purchasing live poultry, and cleaning up poultry feathers..$^{20}$

Among studies looking at non-commercial poultry workers (i.e. backyard farmers), four of the seven studies found low levels of serological activity to AIV, but the remaining three did not.

The four studies investigating AIV in other workers (i.e. non-farming) demonstrated serological activity against AIV in a small number of their participants.

\section{IV.2.2 Secondary transmission of AIV}

Four of the 30 avian studies tested household contacts of workers for potential AIV infection. Among 28 family members of five confirmed $\mathrm{H} 5 \mathrm{~N} 1$ cases, only one individual produced a positive sample by MN assay. ${ }^{21}$ In another study, 56 out of 62 household members (who had no exposure to poultry) of poultry workers with confirmed A/ H7N7 submitted a serum sample at least three weeks after diagnosis of the primary case. Of the 62 individuals, eight reported health complaints and two met the case definitions for both conjunctivitis and ILI. Of the 56 individuals who provided a serum sample, 33 had detectable antibodies against $\mathrm{H} 7 .{ }^{22} \mathrm{~A}$ sample of workers taken from an existing Agricultural Health Survey being conducted in lowa used the unexposed spouses of the rural agriculture workers exposed to poultry as their comparison group. Over a 24 month period, three individuals in the control group demonstrated titre levels $\geq 1: 20$ for $\mathrm{H} 4, \mathrm{H} 5, \mathrm{H6}$, and $\mathrm{H} 9$. One individual had a titre of $\geq 1: 80$ to $\mathrm{H} 9 .{ }^{23}$ Outbreak surveillance during an $\mathrm{H} 7$ outbreak in the Netherlands in 2003 confirmed A/H7 in three household contacts of a poultry worker or farmer. ${ }^{24}$

\section{IV.2.3 Swine influenza virus in individuals occupationally exposed to swine}

Thirteen of the 43 articles assessed the seroprevalence of SwIV in humans. Eleven studies were conducted in workers from commercial farms, and two studies were conducted in community farms. Seropositive individuals were detected in all studies, and Gray et al (2007) was able to isolate SwIV from a symptomatic individual. ${ }^{25}$ The number of individuals found to be seropositive to at least one SwIV ranged between 1-2 individuals to up to 47 individuals, depending on the study.

Beaudoin et al (2010) compared employees from two large, comparable swine farms, where one farm was known to have H2N3-positive swine. Four participants were H2N3 positive, only one of which worked on the exposed farm. It was postulated that seropositivity may have been unrelated to recent exposure. Three of the four participants were born before 1968, with the individual who worked on the exposed farm born in 1949; serological activity could be the result of cross-reactivity to previously circulating human H2N3.

Although individuals with swine exposure did produce a greater serological response, Gerloff et al (2011) ${ }^{26}$ did not detect a statistically significant difference between the serological responses of healthy individuals with past or present professional exposure to swine and control serum samples from the general population.

\section{IV.2.4 Secondary transmission of SwIV}

Two articles evaluated potential household transmission of SwIV from workers. Using a sample of swine workers and their unexposed spouses from the lowa Agriculture Health Survey, spouses were at an increased risk for H1N1 SwIV compared to unexposed university controls, with adjusted odds ratio of 28.2 (95\% Cl: 6.1, 130.1). Swine workers had an adjusted odds ratio of 54.9 (95\% Cl: 12.0, 232.6). ${ }^{25}$ Robinson et al (2007) $)^{27}$ investigated members of a communal farm where an infant had been hospitalized due to a swine-related influenza virus (confirmed). Eight members from three households (including four members from the household of the index patient) were seropositive (titres $\geq 32$ ). Most had no exposure to swine or $<1$ hour per week of exposure. One of ten swine serum samples tested was seropositive for the same strain that infected the index patient. ${ }^{27}$ 


\section{IV.2.5 Influenza vaccination among all occupationally exposed individuals}

Information on vaccination history was collected in 22 of the studies and results ranged from workers receiving seasonal influenza in the past year, to never having received seasonal influenza vaccine. One study asked specifically about receiving the 1976 swine influenza vaccine. Vaccination rates ranged from 0 to approximately $60 \%$ in the study population. In control groups, vaccination rates were as high as $76 \% .{ }^{18}$ The wide variation in vaccination rates can potentially be attributed to factors such as vaccine access, living in an urban or rural region, keeping a backyard farm or working on a commercial farm.

\section{IV.2.6 Existing influenza vaccination recommendations for occupationally exposed individuals}

From a rapid review limited to the English and French language, a small number of countries have existing national recommendations for seasonal influenza vaccination that specifically mention workers with occupational exposure to animals (Appendix B).

In Canada, $\mathrm{NACl}$ recommends that people in direct contact with infected poultry during culling operations, such as cullers, supervising veterinarians and inspectors, receive influenza vaccination. The Canadian Food Inspection Agency (CFIA) uses the broader NACI statement that encourages all healthy Canadians aged 6 months and older get the seasonal vaccine, to encourage all individuals involved in the food production system (e.g. producers and their families, farm workers, veterinarians, farm service personnel, people visiting swine operations) to receive the vaccine as a biosecurity measure.

In the United States, the Centers for Disease Control and Prevention (CDC) issued a statement in 2010 that made a universal recommendation for seasonal influenza vaccination which also explicitly recommended that persons who are charged with responding to avian influenza outbreaks in poultry receive the seasonal influenza vaccine. ${ }^{28}$ The 2012 update to the statement did not address this recommendation. ${ }^{29}$ With the recent activity involving the $2011 \mathrm{H} 3 \mathrm{~N} 2$ variant virus, the $\mathrm{CDC}$ released interim guidance for workers employed at commercial swine farms recommending seasonal influenza vaccination for the purposes of reducing the risk of transmitting seasonal influenza viruses from ill people to pigs. ${ }^{30}$
In Australia, the Australian Immunisation Handbook recommends seasonal influenza vaccination during confirmed avian influenza activity to individuals involved in the commercial poultry industry or in culling. However, this recommendation is not stated in the annual seasonal influenza statements produced by the Australian Technical Advisory Group on Immunisation (ATAGI).

The Hong Kong Department of Health recommends seasonal influenza vaccine for poultry farmers and additionally to pig farmers and individuals in the pigslaughtering industry.

Beginning in the 2006/07 season, an annual seasonal influenza program was implemented in the United Kingdom for poultry workers. However, because of difficulties running the program and low vaccine uptake, the program ended after the 2010/11 season. The recommendation for vaccinating poultry workers, considered a low priority group, was also rescinded. Swine workers were assessed in 2006 and 2009 as a potential target group for vaccination, but no recommendation has been made by the Joint Committee on Vaccination and Immunisation due to limited evidence.

The number of countries sampled was limited by the language restrictions placed on the search. An analysis was conducted by the Vaccine European New Integrated Collaboration Effort Project of national influenza vaccination polices across the European Union, Norway and Iceland in 2009. ${ }^{31}$ Of the 27 countries surveyed, 13 (48\%) recommended seasonal influenza vaccine for workers in the poultry industry, and 9 (33\%) recommended vaccination for individuals in veterinary services. In a second survey, to which 26 countries responded, 4 countries (15\%) recommend that families raising poultry also receive the influenza vaccine. However, recommendations are often in flux and the authors noted that several countries had modified their vaccination policies since the initial surveys were conducted.

\section{IV.3 IWG MEETING WITH ANIMAL HEALTH EXPERTS}

The IWG held an ad hoc meeting in December 2012 in order to discuss the current vaccination practices of swine and poultry workers, the biosecurity measures used in the industry, and risk of cross-species influenza transmission with members of the Avian Flu Task Group from the joint committee of the Chief Medical Officers of Health, as well as the Chief Veterinary Officers. The following is a synopsis of that discussion. ${ }^{32,33}$ 
Most Canadian swine veterinarians are members of professional associations that already have position statements in favour of seasonal vaccination, and most veterinarians are aware of these recommendations. The uptake is unknown, however. The Canadian Swine Health Board issued a press release encouraging all barn staff and veterinarians to be vaccinated. They held a vaccination clinic at their October 2012 meeting, and some Canadian swine workers are aware of the board's encouragement to have their influenza vaccination.

Many larger farms in the swine industry already require their staff to be vaccinated against influenza, but it is difficult to mandate and so, in general, they make recommendations, offer vaccination clinics and try to educate staff. After H1N1, it has become more widely accepted that humans may be a source of influenza infection for swine. Some swine farms now will not allow people to enter the barns if they have symptoms of influenza like illness.

The way humans and pigs interact in Canada is slightly different than the way they interact in the USA. Canada has a smaller pig industry, a smaller human population, and fewer farm fairs. As a result, there are fewer human-swine interactions involving the general public. Canadian farms generally have stricter biosecurity measures and most swine are confined to the indoors all year due to the colder weather. Many areas vaccinate their swine, although not always on an annual basis due to cost. Swine influenza strains do not tend to change rapidly from year to year in many regions of Canada. However in areas where high numbers of pigs are produced in large farming systems, influenza strains change rapidly, often requiring autogenous vaccination to control symptoms. This is a more common scenario in the USA with its much larger pig production industry. Swine vaccines have the same efficacy

\section{Discussion}

The Rapid Response Report conducted by CADTH was based upon a limited literature search and was not a comprehensive, systematic review. It did provide a summary of the current lack of evidence on the topic of influenza vaccination of animal workers for prevention of cross-species infection. As there is no evidence, no conclusions can be drawn regarding the effectiveness of vaccinating this group of workers. challenges as those made for humans; they do not induce protection against other influenza virus strains that can affect the herd. In regions where farms are more spread out, there is less swine influenza virus transmission than in regions where farms are located closer together. There are much regional variation in the distance between farms across both the USA and Canada.

Bio-security is the major means of prevention of avian influenzas as well. Notifiable avian influenza is reportable in Canada and there is surveillance and the authority to respond if an outbreak is detected, regardless of the pathogenicity. Some producers have their own recommendation that a worker be vaccinated before starting to work with poultry, but these recommendations are not mandatory. In contrast to swine, influenza viruses are not routinely found in commercial poultry in Canada. Birds are not as susceptible to infection with human influenza viruses due to differences between avian and mammalian receptors. Mammals (e.g. swine, ferrets, dogs, cats) are more likely to share influenza viruses with humans.

There is also a growing segment of the human population in both Canada and the USA that is raising pigs and poultry on a smaller scale outside of the commercial industry. These are often referred to as "backyard producers" and usually sell their products at local farmer's markets or directly to the public. They frequently advertise their products as being healthier than products from the commercial industry, and thus do not always see a need for biosecurity or disease control. These producers may not be as well informed about biosecurity or disease, and often apply fewer biosecurity measures. The general public often can directly contact the live animals on these farms. Because this segment is not represented by an industry organization, they can be more difficult to reach and educate.

The transmission of avian and swine influenza to the humans that handle these animals is documented in the literature, but because of a number of study limitations, the true extent of the burden of cross-species transmission is difficult to determine.

One limitation of the literature review is due to the fact that standard testing protocols for assessing human immune response to influenza strains that have not adapted to 
human-to-human transmission do not exist, with the exception of H5N1. ${ }^{34}$ This is a significant issue impacting study comparability as authors take different approaches to assess immunological outcomes. Some authors assume that an individual infected with an animal influenza strain would generate low antibody titres that return to preinfection levels within a short period of time. In these cases, lower cut-offs were used to determine seropositivity (e.g. titres $\geq 1: 10$ or $\geq 1: 20$ ). Other studies used existing testing protocols as a guideline, and used higher cut-offs (e.g. titres $\geq 1: 80$ or $\geq 1: 160$ ), which could potentially underestimate the frequency of cross-species infection.

The type of assay used to titre antibody responses also affects results. MN assays were considered by some studies to be the preferred assay for assessing seroresponse because it is highly sensitive and specific. Almost all studies used the hemaglutination inhibition $(\mathrm{HI})$ assay, ${ }^{35}$ but varied the erythrocyte species used. The $\mathrm{HI}$ assay is strain dependent, and if there is a mismatch between the assay and sample strains, the assay is limited in its ability to detect an immune response in an individual who was otherwise infected and capable of mounting a response.
Cross-reactivity between swine, avian and human influenza viruses is another confounding factor that only one study accounted for, which may lead to an erroneous increase in positive results. It can be difficult to identify the potential cross-reactions that could occur, thereby limiting the ability to tease out the impact it may have on the outcome. Cross-reactivity may be more significant in SwIV-related studies. Although there were a limited number of studies, seroresponse to SwIV appeared to be more prevalent than seroresponse to AIV. One study noted that age may be a factor as older individuals may have acquired immunity to influenza strains of interest that possibly re-emerged after a dormant period, ${ }^{36}$ and another alluded to the role of influenza vaccination causing cross-reactions during testing.

The discussion with the members of the Avian Flu Task Group and the Chief Veterinary Officers indicated that there are current seasonal vaccination recommendations in place by the various professional associations, and that most veterinarians are aware of these recommendations. The uptake, however, is unknown. The strict biosecurity measures in Canada are the major means of prevention of avian and swine influenza infection.

\section{Recommendations/Rationale}

Direct contact with infected poultry, or surfaces and objects contaminated by their droppings, is currently considered the primary route through which workers become infected with avian influenza. As cullers are in an environment with a high concentration of infected poultry, surfaces and objects, this presents an opportunistic setting for viral transmission. Infected poultry can shed large quantities of virus in their droppings and respiratory secretions, and the culling process may result in a higher than normal exposure to these secretions. Influenza is endemic to the swine population and infections are often mild or asymptomatic. Swine and poultry workers are not likely to experience the same intensity of exposure to virus particles as are cullers. It was noted in the literature review that poultry cullers had more frequent positive serology results against avian influenza than other poultry workers. For these reasons, the recommendations for poultry works involved in culling operations differ from those made for poultry and swine workers.

\section{VI.1 POULTRY WORKERS}

$\mathrm{NACl}$ continues to recommend immunization against seasonal influenza for people in direct contact during culling operations involving poultry infected with avian influenza (NACI recommendation grade I); however $\mathrm{NACl}$ encourages influenza vaccine for all Canadians age 6 months and older.

Based on a review of the literature and a discussion with animal health experts, $\mathrm{NACl}$ has concluded that there is no direct evidence of the efficacy of vaccinating poultry workers to prevent reassortment of avian and seasonal human strains in humans leading to emergence of pandemic viruses. However, the literature documents the transmission of avian influenza to humans that manipulate poultry as a food source. The contact is usually close and sustained with the animal (for example, culling); and the risk of transmission is relatively low. In the small number of studies that assessed both poultry workers and cullers, cullers constituted the majority of the seropositive cases. It can be hypothesized that contact between a worker involved in culling poultry that are infected with avian influenza would be more prolonged and significant than other types of contact with poultry. 
There is evidence that avian and human viruses can reassort and that this reassortment can occur in humans. Influenza does not usually circulate in commercial poultry in Canada and all highly pathogenic avian and any avian strain of $\mathrm{H} 5$, $\mathrm{H} 7$ are reportable in Canada according to the animal health experts that $\mathrm{NACl}$ consulted. Many jurisdictions internationally have a similar recommendation. Based on what is currently known about influenza viruses and reassortment, $\mathrm{NACl}$ is of the opinion that immunizing poultry workers against seasonal influenza could prevent reassortment in humans between the avian strain in an outbreak and seasonal strains in humans. However, given the variable efficacy of the seasonal influenza vaccine in healthy adults and in adults with chronic health conditions, the two week period from immunization to development of immunity and the theoretical benefit, seasonal influenza immunization to prevent reassortment of viral strains should be used as a complementary measure to other biosecurity measures that have been described elsewhere (e.g. antivirals and personal protective equipment). ${ }^{37}$ Also, seasonal influenza vaccine should not be expected to be efficacious against avian strains of influenza given the significant antigenic difference between strains (e.g. H7N3, H9N2).

\section{VI.2 SWINE WORKERS}

$\mathrm{NACl}$ concludes that there is insufficient evidence at this time to specifically recommend routine influenza immunization for swine workers ( $\mathrm{NACl}$ recommendation grade I); however $\mathrm{NACl}$ encourages influenza vaccine for all Canadians age 6 months and older.

Based on a review of the literature and a discussion with animal health experts, $\mathrm{NACl}$ has concluded that there is currently no direct evidence that immunizing these workers would prevent the emergence of pandemic strains. This would also not be feasible to study. However, based on what is known about transmission and reassortment of swine and human strains, from a theoretical perspective there could be a benefit.

Notwithstanding this statement, $\mathrm{NACl}$ continues to encourage influenza vaccine for all Canadians six months of age and older to provide protection to those who wish to take advantage of this vaccine.
The provision of recommendations regarding immunization of swine workers as a means to protect swine herds is not within the scope of $\mathrm{NACl}$. For animal health concerns, the reader should refer to appropriate animal health resources.

Objectives of immunization of swine workers against seasonal influenza can vary:

- Protecting the herds against human strains of influenza;

- Protecting the workers against antigenically related emerging swine strains; and/or

- Preventing reassortment of swine and human strains into pandemic strains.

The burden of transmission between swine and workers in Canada is not well known. Unlike influenza outbreaks in poultry, swine outbreaks of influenza are not reportable in Canada. One study carried out in Alberta in a limited number of commercial farms concluded that the transmission risk from swine to workers and vice versa was low. ${ }^{38}$ According to the animal experts with whom $\mathrm{NACl}$ consulted, farming operations in Canada involving swine usually apply several biosecurity measures. However, the protection attributable to the human vaccine compared to the other biosecurity measures is unknown. Also, compared to other jurisdictions, the opportunity for direct contact between live swine and the general public is limited in Canada. However, not all farms will apply biosecurity measures equally and there will be some unprotected workers exposed directly to swine in close quarters on a daily basis in Canada. Transmission of swine virus variants to swine workers and their close contacts has been documented in the literature. Because many influenza infections in humans and swine are likely not reported or confirmed, transmission may be underreported in the literature. In conclusion, the risk of influenza transmission between people and swine is likely low for the general public in Canada. Swine workers in both commercial and backyard operations will be at a higher risk than the general public. 
Few countries have implemented a recommendation for the seasonal vaccination of swine workers. During the 2006/2007 influenza season, the United Kingdom implemented an annual seasonal influenza program for poultry workers, but the program ended after the 2010/2011 season due to logistical issues, low vaccine uptake, and the consideration that poultry workers are seen as a low priority group. In Canada, recommendations vary: some provinces currently recommend immunization of swine workers; one province recommends against immunization, and one province had a recommendation and then removed it following studies in 2009 that showed an association between receipt of seasonal immunization and infection with pandemic H1N1 strain. ${ }^{39}$ Some studies have shown similar results in ferrets and swine after receiving a seasonal vaccine and being challenged with the pandemic H1N1 2009 strain. ${ }^{40,41}$ CFIA recommends immunization of swine workers against seasonal influenza. One reason for this is to protect the herds against infection with human influenza strains. However, this is outside of the scope of $\mathrm{NACl}$.
In the context of the emergence of a swine variant virus, the effectiveness of influenza immunization of swine workers would largely depend on the antigenic similarity between the emergent strain and the seasonal influenza vaccine formulation available that particular season.

$\mathrm{NACl}$ concludes that with the emergence of a swine variant virus, the virulence of the disease for both swine and humans and vaccine effectiveness in humans are likely to vary and would need to be assessed on a case by case basis to determine if the risk benefit profile favors an immunization recommendation.

Finally, the safety of the influenza vaccine has been documented in adults and important adverse events are quite uncommon, the most common side effect being minor pain at the site of injection for a few days following intra muscular injection. The safety section of the 20132014 Influenza Statement can be consulted for more details about the safety of these vaccines. 


\section{References}

(1) Yan S, Wu G. Evidence obtained from ANOVA to reason cross-species infection and cross-subtype mutation in neuraminidases of influenza A viruses. Transbound Emerg Dis. 2010;57(4):254-261.

(2) World Health Organization. Cumulative number of confirmed human cases of avian influenza $\mathrm{A}(\mathrm{H} 5 \mathrm{~N} 1)$ reported to WHO, 2013 www.who.int/influenza/ human_animal_interface/H5N1_cumulative_table_ archives/en.

(3) Canadian Food Inspection Agency. Avian Influenza Surveillance www.inspection.gc.ca/animals/terrestrialanimals/diseases/surveillance/avian-influenzasurveillance/eng/1329693810008/1329694298513, 2013.

(4) Nelli RK, Kuchipudi SV, White GA, Perez BB, Dunham $\mathrm{SP}$, Chang KC. Comparative distribution of human and avian type sialic acid influenza receptors in the pig. BMC Vet Res. 2010;6:4-6148-6-4.

(5) Van Poucke SG, Nicholls JM, Nauwynck HJ, Van Reeth K. Replication of avian, human and swine influenza viruses in porcine respiratory explants and association with sialic acid distribution. Virol J. 2010;7:38-422X-7-38.

(6) United States Department of Agriculture: Animal and Plant Health Inspection Service. Swine Influenza Surveillance www.aphis.usda.gov/animal_health/ animal_dis_spec/swine/siv_surveillance.shtml 2013.

(7) World Health Organization. Pandemic influenza preparedness and response: WHO guidance document. 2009.

(8) World Health Organization. Avian influenza: Assessing the pandemic threat. 2005.

(9) Garten RJ, Davis CT, Russell CA, et al. Antigenic and genetic characteristics of swine-origin 2009 A(H1N1) influenza viruses circulating in humans. Science. 2009;325(5937):197-201.

(10) Canadian Agency for Drugs and Technologies in Health (CADTH). Influenza vaccination for prevention of cross-species infection: A review of the clinical evidence. 2012.
(11) Cai W, Schweiger B, Buchholz U, et al. Protective measures and $\mathrm{H} 5 \mathrm{~N} 1$-seroprevalence among personnel tasked with bird collection during an outbreak of avian influenza $\mathrm{A} / \mathrm{H} 5 \mathrm{~N} 1$ in wild birds, Ruegen, Germany, 2006. BMC Infectious Diseases. 2009;9:170.

(12) Alizadeh E, Kheiri MT, Bashar R, Tabatabaeian M, Hosseini SM. Avian influenza (H9N2) among poultry workers in lan. Iranian Journal of Microbiology; 2009.1: 3, 3-6.13 ref. 2009.

(13) Arzey GG, Kirkland PD, Arzey KE, et al. Influenza virus a (H1ON7) in chickens and poultry abattoir workers, Australia. Emerging Infectious Diseases. 2012;18(5):814-816.

(14) Bridges CB, Lim W, Hu-Primmer J, et al. Risk of influenza A (H5N1) infection among poultry workers, Hong Kong, 1997-1998. J Infect Dis. 2002;185(8):1005-1010.

(15) Kwon D, Lee J-, Choi W, et al. Avian influenza A (H5N1) virus antibodies in poultry cullers, South Korea, 2003-2004. Emerging Infectious Diseases. 2012;18(6):986-988.

(16) Ortiz JR, Katz MA, Mahmoud MN, et al. Lack of evidence of avian-to-human transmission of avian influenza $A$ ( $H 5 N 1$ ) virus among poultry workers, Kano, Nigeria, 2006. J Infect Dis. 2007;196(11):1685-1691.

(17) Schultsz C, Nguyen VD, Hai le T, et al. Prevalence of antibodies against avian influenza $A$ (H5N1) virus among cullers and poultry workers in Ho Chi Minh City, 2005. PLoS ONE. 2009;4(11):e7948.

(18) Gray GC, Ferguson DD, Lowther PE, Heil GL, Friary JA. A national study of US bird banders for evidence of avian influenza virus infections. Journal of Clinical Virology. 2011;51(2):132-135.

(19) Shafir SC, Fuller T, Smith TB, Rimoin AW. A national study of individuals who handle migratory birds for evidence of avian and swine-origin influenza virus infections. J Clin Virol. 2012;54(4):364-367.

(20) Vong S, Coghlan B, Mardy S, et al. Low frequency of poultry-to-human $\mathrm{H} 5 \mathrm{NI}$ virus transmission, Southern Cambodia, 2005. Emerging Infectious Diseases. 2006;12(10):1542-1547. 
(21) Ceyhan M, Yildirim I, Ferraris $O$, et al. Serosurveillance study on transmission of H5N1 virus during a 2006 avian influenza epidemic. Epidemiology \& Infection. 2010;138(9):1274-1280.

(22) Du Ry van Beest Holle,M., Meijer A, Koopmans M, de Jager CM. Human-to-human transmission of avian influenza A/H7N7, the Netherlands, 2003. Euro surveillance : bulletin europeen sur les maladies transmissibles $=$ European communicable disease bulletin. 2005;10(12):264-268.

(23) Gray GC, McCarthy T, Capuano AW, Setterquist SF, Alavanja MC, Lynch CF. Evidence for avian influenza A infections among iowa's agricultural workers. Influenza and other Respiratory Viruses. 2008;2(2):61-69.

(24) Koopmans M, Wilbrink B, Conyn M, et al. Transmission of H7N7 avian influenza A virus to human beings during a large outbreak in commercial poultry farms in the Netherlands. Lancet. 2004;363(9409):587-593.

(25) Gray GC, Trampel DW, Roth JA. Pandemic influenza planning: Shouldn't swine and poultry workers be included? Vaccine. 2007;25(22):4376-4381.

(26) Gerloff NA, Kremer JR, Charpentier E, et al. Swine influenza virus antibodies in humans, Western Europe, 2009. Emerging Infectious Diseases. $2011 ; 17(3): 403-411$.

(27) Robinson JL, Lee BE, Patel J, et al. Swine influenza (H3N2) infection in a child and possible community transmission, Canada. Emerging Infectious Diseases. 2007;13(12):1865-1870.

(28) Centers for Disease Control and Prevention (CDC). Morbidity and mortality weekly report-prevention and control of influenza with vaccines: Recommendations of the advisory committee on immunization practices (ACIP), 2010. August 6, 2010/59(rr08);1-62.

(29) Centers for Disease Control and Prevention (CDC). Morbidity and mortality weekly report-prevention and control of influenza with vaccines:

Recommendations of the advisory committee on immunization practices (ACIP)_United States, 2012-13 influenza season. 2012;61(32);613-618.
(30) Centers for Disease Control and Prevention (CDC). CDC interim guidance for workers who are employed at commercial swine farms: Preventing the spread of influenza A viruses, 2011.

(31) Mereckiene J, Cotter S, D'Ancona F, et al. Differences in national influenza vaccination policies across the European Union, Norway and Iceland 2008-2009. Eurosurveillance. 2010;15(44).

(32) NACl Influenza Working Group. Record of decisions December 17th, 2012.

(33) NACl Influenza Working Group. Anonymous .

(34) Global Influenza P. Expert consultation on diagnosis of $\mathrm{H} 5 \mathrm{~N} 1$ avian influenza infections in humans. Influenza \& Other Respiratory Viruses. 2007;1(4):131-138.

(35) Rowe T, Abernathy RA, Hu-Primmer J, et al. Detection of antibody to avian influenza $A$ (H5N1) virus in human serum by using a combination of serologic assays. J Clin Microbiol. 1999;37(4):937-943.

(36) Beaudoin A, Gramer M, Gray GC, Capuano A, Setterquist $S$, Bender J. Serologic survey of swine workers for exposure to H2N3 swine influenza A. Influenza and other Respiratory Viruses. 2010;4(3):163-170.

(37) Canadian Food Inspection Agency. Animal Biosecurity www.inspection.gc.ca/animals/ terrestrial-animals/biosecurity/eng/1299868055616/ 1320534707863, 2013-02-05.

(38) J. Keenliside. NACI IWG. Communication regarding unpublished Canadian swine influenza study, April 29, 2013.

(39) Skowronski DM, de Serres G, Crowcroft NS, et al. Association between the 2008-09 seasonal influenza vaccine and pandemic H1N1 illness during springsummer 2009: Four observational studies from Canada. PLoS Medicine. 2010;7(4).

(40) Ellebedy AH, Ducatez MF, Duan S, et al. Impact of prior seasonal influenza vaccination and infection on pandemic A (H1N1) influenza virus replication in ferrets. Vaccine. 2011;29(17):3335-3339.

(41) Zhu H, Wang J, Zheng Z, et al. Pathogenicity and transmissibility of the pandemic H1N1 2009-related influenza viruses in mice, ferrets, and pigs. Influenza \& Other Respiratory Viruses. 2011;5(Suppl 1):82-84. 
(42) Dejpichai R, Laosiritaworn Y, Phuthavathana P, et al. Seroprevalence of antibodies to avian influenza virus A (H5N1) among residents of villages with human cases, Thailand, 2005. Emerging Infectious Diseases. 2009;15(5):756-760.

(43) Gray GC, McCarthy T, Capuano AW, Setterquist SF, Alavanja MC, Lynch CF. Evidence for avian influenza A infections among lowa's agricultural workers. Influenza \& Other Respiratory Viruses. 2008;2(2):61-69.

(44) Hinjoy S, Puthavathana P, Laosiritaworn Y, et al. Low frequency of infection with avian influenza virus (H5N1) among poultry farmers, Thailand, 2004. Emerg Infect Dis. 2008;14(3):499-501.

(45) Holle, M. R. D. R. van B., Setiawaty V, Pangesti KNA, Sedyaningsih ER. Seroprevalence of avian influenza A/H5N1 among poultry farmers in rural Indonesia, 2007. Southeast Asian Journal of Tropical Medicine and Public Health; 2010.41: 5, 1095-1103.14 ref. 2010.

(46) Huo X, Zu R, Qi X, et al. Seroprevalence of avian influenza $A(H 5 N 1)$ virus among poultry workers in Jiangsu province, China: An observational study. BMC Infectious Diseases. 2012;12.

(47) Jia N, de Vlas SJ, Liu YX, et al. Serological reports of human infections of $\mathrm{H} 7$ and $\mathrm{H} 9$ avian influenza viruses in Northern China. Journal of Clinical Virology. 2009;44(3):225-229.

(48) Kayali G, Ortiz EJ, Chorazy ML, Gray GC. Evidence of previous avian influenza infection among US turkey workers. Zoonoses and public health. 2010;57(4):265-272.

(49) Kayali. Evidence of infection with $\mathrm{H} 4$ and $\mathrm{H} 11$ avian influenza viruses among Lebanese chicken growers. PLOS ONE. 2011;6(10):e26818.

(50) Khuntirat BP, Yoon InKyu, Blair PJ, et al. Evidence for subclinical avian influenza virus infections among rural Thai villagers. Clinical Infectious Diseases. 2011.

(51) Koopmans M, Wilbrink B, Conyn M, et al. Transmission of H7N7 avian influenza A virus to human beings during a large outbreak in commercial poultry farms in the Netherlands. Lancet. 2004;363(9409):587-593.
(52) Leibler JH, Silbergeld EK, Pekosz A, Gray GC. No evidence of infection with avian influenza viruses among US poultry workers in the Delmarva Peninsula, Maryland and Virginia, USA. J Agromed. 2011;16(1):52-57.

(53) Lu CiYong, Lu JiaHai, Chen WeiQing, et al. Potential infections of H5N1 and H9N2 avian influenza do exist in Guangdong populations of China. Chin Med J. 2008(Beijing):121: 20, 2050-2053. 18 ref.

(54) Ogata T, Yamazaki Y, Okabe N, et al. Human H5N2 avian influenza infection in Japan and the factors associated with high $\mathrm{H} 5 \mathrm{~N} 2$-neutralizing antibody titer. Journal of Epidemiology; 2008.18: 4, 160166.20 ref. 2008.

(55) Ortiz EJ, Kochel TJ, Capuano AW, Setterquist SF, Gray GC. Avian influenza and poultry workers, Peru, 2006. Influenza and other respiratory viruses. 2007;1(2):65-69.

(56) Ortiz JR, Katz MA, Mahmoud MN, et al. Lack of evidence of avian-to-human transmission of avian influenza A (H5N1) virus among poultry workers, Kano, Nigeria, 2006. J Infect Dis. 2007;196(11):1685-1691.

(57) Pawar SD, Tandale BV, Raut CG, et al. Avian influenza H9N2 seroprevalence among poultry workers in Pune, India, 2010. PLoS ONE. 2012;7 (5), 18 May 2012.

(58) Puzelli S, Di Trani L, Fabiani C, et al. Serological analysis of serum samples from humans exposed to avian $\mathrm{H} 7$ influenza viruses in italy between 1999 and 2003. J Infect Dis. 2005;192(8):1318-1322.

(59) Santhia K, Ramy A, Jayaningsih P, et al. Avian influenza A H5N1 infections in Bali province, Indonesia: A behavioral, virological and seroepidemiological study. Influenza and other respiratory viruses. 2009;3(3):81-89.

(60) Wang M, Fu CX, Zheng BJ. Antibodies against H5 and $\mathrm{H} 9$ avian influenza among poultry workers in China. N Engl J Med. 2009;360(24):2583-2584.

(61) Yamazaki Y, Doy M, Okabe N, et al. Serological survey of avian H5N2-subtype influenza virus infections in human populations. Arch Virol. 2009;154(3):421-427. 
(62) Ayora-Talavera G, Cadavieco-Burgos JM, CanulArmas AB. Serologic evidence of human and swine influenza in Mayan persons. Emerging Infectious Diseases. 2005;11(1):158-161.

(63) Gray GC, McCarthy T, Capuano AW, et al. Swine workers and swine influenza virus infections. Emerging Infectious Diseases. 2007;13(12):1871-1878.

(64) Kitikoon P, Sreta D, Tuanudom R, et al. Serological evidence of pig-to-human influenza virus transmission on Thai swine farms. Vet Microbiol. 2011;148(2-4) (pp 413-418):ate of Pubaton: 24 Mar 2011.

(65) Krumbholz A, Lange J, Durrwald R, et al. Prevalence of antibodies to swine influenza viruses in humans with occupational exposure to pigs, Thuringia, Germany, 2008-2009. J Med Virol. 2010;82(9):1617-1625.

(66) Lopez-Robles G, Montalvo-Corral M, Caire-Juvera G, Ayora-Talavera G, Hernandez J. Seroprevalence and risk factors for swine influenza zoonotic transmission in swine workers from northwestern Mexico. Transbound Emerg Dis. 2012;59(2):183-188.

(67) Myers KP, Olsen CW, Setterquist SF, et al. Are swine workers in the United States at increased risk of infection with zoonotic influenza virus. Clinical Infectious Diseases. 2006;42(1):14-20.
(68) Olsen CW, Brammer L, Easterday BC, et al. Serologic evidence of $\mathrm{H} 1$ swine influenza virus infection in swine farm residents and employees. Emerging Infectious Diseases; 2002.8: 8, 814-819.37 ref. 2002.

(69) Olsen CW, Karasin Al, Carman S, et al. Triple reassortant H3N2 influenza A viruses, Canada, 2005. Emerging Infectious Diseases. 2006;12(7):1132-1135.

(70) Ramirez A, Capuano AW, Wellman DA, Lesher KA, Setterquist SF, Gray GC. Preventing zoonotic influenza virus infection. Emerging infectious diseases. 2006;12(6):996-1000.

(71) Robinson JL, Lee BE, Patel J, et al. Swine influenza (H3N2) infection in a child and possible community transmission, Canada. Emerging Infectious Diseases. 2007;13(12):1865-1870.

(72) Terebuh P, Olsen CW, Wright J, et al. Transmission of influenza A viruses between pigs and people, lowa, 2002-2004. Influenza and other Respiratory Viruses. 2010;4(6):387-396.

(73) Harris RP, Helfand M, Woolf SH, et al. Current methods of the US preventive services task force: A review of the process. Am J Prev Med. 2001;20(3 Suppl):21-35. 


\section{Appendix A: Summary of Evidence for NACI Recommendation}

\begin{tabular}{|c|c|c|c|c|c|c|}
\hline \multicolumn{7}{|c|}{ INDIVIDUALS WITH OCCUPATIONAL EXPOSURE TO AVIAN POPULATIONS } \\
\hline Study & Study Design & Participants & Influenza type & Key findings & Level & Quality \\
\hline Alizadeh E (2009) ${ }^{12}$ & $\begin{array}{l}\text { Cross-sectional } \\
\text { seroprevalence }\end{array}$ & $\begin{array}{l}\mathrm{N}=152 \\
\mathrm{n}_{\text {exposed }}=127 \\
\mathrm{n}_{\text {control }}=25 \\
\text { Poultry and } \\
\text { slaughter-house } \\
\text { workers (all men); } \\
\text { Controls with } \\
\text { regular consumer } \\
\text { related poultry } \\
\text { exposure (60\% } \\
\text { females) } \\
\text { Iran, Nov } 2006\end{array}$ & $\begin{array}{l}\text { Avian } \\
\text { H9N2 } \\
\text { H7N7 }\end{array}$ & $\begin{array}{l}\mathrm{HI} \text { assay (WHO protocol), } \\
\text { adjusted for potential } \\
\text { cross-reactivity between } \\
\mathrm{H} 3 \text { and } \mathrm{H} 9 \\
48 \text { workers ( } 37.7 \%) \text { were } \\
\text { seropositive (titres } \geq 1: 20 \text { ) } \\
\text { Seropositivity in slaughter- } \\
\text { house workers was } 2.09 \\
\text { times higher than poultry } \\
\text { workers (51.6\% vs. 24.6\%) } \\
\text { 83.3\% (20/24) evisceration } \\
\text { workers were seropositive } \\
\text { H7N7 not detected }\end{array}$ & III & Good \\
\hline Arzey GG (2012) $)^{13}$ & $\begin{array}{l}\text { Cross-sectional, } \\
\text { serological } \\
\text { testing }\end{array}$ & $\begin{array}{l}\mathrm{n}=7 \\
\text { Symptomatic } \\
\text { abattoir workers } \\
\text { from a biosecure } \\
\text { intensive } \\
\text { commercial } \\
\text { poultry enterprise } \\
\text { experiencing an } \\
\text { outbreak of low } \\
\text { pathogenic avian } \\
\text { influenza A } \\
\text { Australia, } \\
\text { Mar } 2010\end{array}$ & $\begin{array}{l}\text { Avian } \\
\text { H10N7 }\end{array}$ & $\begin{array}{l}\text { HI assay, MN assay } \\
\text { Workers showed signs of } \\
\text { conjunctivitis, with } 2 \\
\text { reporting rhinorrhea and } 1 \\
\text { reporting sore throat } \\
\text { Conjunctival swabs } \\
\text { collected from } 6 \text { workers, } \\
\text { nose and throat swabs } \\
\text { collected from all workers } \\
\text { Partial sequence analysis of } \\
\text { samples from two workers } \\
\text { confirmed presence of } \\
\text { influenza A subtype H10 } \\
\text { (similar to subtype H10 } \\
\text { chicken isolate) but no } \\
\text { virus cultured from workers } \\
\text { PPE was not frequently } \\
\text { used during the outbreak }\end{array}$ & III & $\begin{array}{l}\text { Good } \\
\text { Confirmed H10 } \\
\text { in poultry flocks }\end{array}$ \\
\hline
\end{tabular}




\begin{tabular}{|c|c|c|c|c|c|c|}
\hline \multicolumn{7}{|c|}{ INDIVIDUALS WITH OCCUPATIONAL EXPOSURE TO AVIAN POPULATIONS } \\
\hline Study & Study Design & Participants & Influenza type & Key findings & Level & Quality \\
\hline Bridges CB (2002) $)^{14}$ & $\begin{array}{l}\text { Serological } \\
\text { testing with } \\
\text { nested } \\
\text { case-control } \\
\text { analysis }\end{array}$ & $\begin{array}{l}\mathrm{N}=1818 \\
\mathrm{n}_{\text {worker }}=1525 \\
\mathrm{n}_{\text {gov }}=293 \\
\text { Poultry and } \\
\text { government } \\
\text { workers involved } \\
\text { in poultry culling } \\
\text { Hong Kong, } \\
\text { 1997-1998 }\end{array}$ & $\begin{array}{l}\text { Avian } \\
\text { A/Duck/ } \\
\text { Singapore/-Q/ } \\
\text { F119-3/97 (H5N3) }\end{array}$ & $\begin{array}{l}\text { MN assay with } \\
\text { confirmatory Western blot; } \\
\text { Seropositive if titres } \geq 80 \\
10 \% \text { ( } n=81 \text { ) of poultry } \\
\text { workers were H5 } \\
\text { seropositive with both } \\
\text { assays; } 29.1 \% \text { ( } n=444 \text { ) of } \\
\text { poultry workers were } \\
\text { seropositive by MN only } \\
\text { Factors statistically } \\
\text { associated with being H5 } \\
\text { seropositive were the } \\
\text { reporting of mortality of } \\
>10 \% \text { of poultry, and } \\
\text { butchering poultry } \\
3 \% \text { ( } n=9 \text { ) of government } \\
\text { workers were H5 } \\
\text { seropositive with both } \\
\text { assays; } 229 \text { workers gave } \\
>1 \text { serum sample and } 1 \\
\text { worker seroconverted } \\
\text { Being a current smoker } \\
\text { was statistically associated } \\
\text { with being H5 seropositive } \\
\text { ( } p=.03 \text { ) in government } \\
\text { workers, but not in poultry } \\
\text { workers }\end{array}$ & $\|-2$ & $\begin{array}{l}\text { Fair } \\
\text { Only } 1 \text { sample } \\
\text { collected from } \\
\text { poultry workers, } \\
\text { therefore } \\
\text { uncertain if } \\
\text { seropositivity } \\
\text { resulted from } \\
\text { current or } \\
\text { previous } \\
\text { exposure }\end{array}$ \\
\hline
\end{tabular}




\begin{tabular}{|c|c|c|c|c|c|c|}
\hline \multicolumn{7}{|c|}{ INDIVIDUALS WITH OCCUPATIONAL EXPOSURE TO AVIAN POPULATIONS } \\
\hline Study & Study Design & Participants & Influenza type & Key findings & Level & Quality \\
\hline Cai W (2009)11 & $\begin{array}{l}\text { Cross sectional } \\
\text { survey with } \\
\text { serological } \\
\text { testing }\end{array}$ & $\begin{array}{l}\mathrm{N}=97 \\
\text { Firemen, } \\
\text { government } \\
\text { workers and } \\
\text { veterinarians } \\
\text { involved in wild } \\
\text { bird collection } \\
\text { during an } \\
\text { outbreak of H5N1 } \\
\text { Germany, } \\
\text { Feb-Mar 2006 } \\
\text { (data collected } \\
\text { Mar 2007) }\end{array}$ & $\begin{array}{l}\text { Human } \\
\text { A/Wisconsin/67/05 } \\
\text { (H3N2) } \\
\text { A/New } \\
\text { Caledonia/20/99 } \\
\text { (H1N1) } \\
\text { Avian } \\
\text { A/whooper swan/ } \\
\text { R65-2/ } \\
\text { Germany/2006 } \\
\text { (H5N1) } \\
\text { A/bar-headed } \\
\text { goose/ } \\
\text { Qinghai/1A/2005 } \\
\text { (H5N1) } \\
\text { A/whooper swan/ } \\
\text { Mongolia/244/2005 } \\
\text { (H5N1) }\end{array}$ & $\begin{array}{l}\text { MN assay, plaque } \\
\text { neutralization-reactive } \\
\text { if anti-H5 titre } \geq 1: 20 ; \\
\text { Cross-reactivity to H1N1 } \\
\text { and H3N2 assessed } \\
\text { 97\% reported using at } \\
\text { least one PPE during bird } \\
\text { collection } \\
7 / 90 \text { (8\%) reported } \\
\text { symptoms of acute } \\
\text { respiratory disease } \\
\text { during the period of } \\
\text { bird collection or up to } \\
5 \text { days after (cough, } \\
\text { cold, headache, } \\
\text { muscle or limb pain) } \\
78 / 97 \text { (80\%) provided } \\
\text { serum samples } \\
5 \text { samples reactive against } \\
\text { H5 with one sample } \\
\text { showing reduced viral } \\
\text { replication upon initial test } \\
\text { (re-testing at WHO gave } \\
\text { negative results); All } 5 \\
\text { samples were firemen and } \\
\text { showed high antibody- } \\
\text { titres against H1N1 }\end{array}$ & III & $\begin{array}{l}\text { Fair } \\
\text { Study } \\
\text { conducted one } \\
\text { year after } \\
\text { outbreak; May } \\
\text { be issues with } \\
\text { recall for survey } \\
\text { questions, and } \\
\text { ability to detect } \\
\text { seroconversion } \\
\text { as H5 declines } \\
\text { quickly } \\
\text { Participation } \\
\text { was lower } \\
\text { among } \\
\text { firefighters } \\
\text { (55\%) compared } \\
\text { to other } \\
\text { participants } \\
\text { (> } 80 \% \text { for } \\
\text { government } \\
\text { workers and } \\
\text { vets) }\end{array}$ \\
\hline
\end{tabular}




\begin{tabular}{|c|c|c|c|c|c|c|}
\hline \multicolumn{7}{|c|}{ INDIVIDUALS WITH OCCUPATIONAL EXPOSURE TO AVIAN POPULATIONS } \\
\hline Study & Study Design & Participants & Influenza type & Key findings & Level & Quality \\
\hline Ceyhan M (2010)21 & $\begin{array}{l}\text { Survey with } \\
\text { serological } \\
\text { testing; Paired } \\
\text { serum sample } \\
\text { collected for } \\
\text { HCWs only, one } \\
\text { sample for } \\
\text { everyone else; } \\
\text { Samples tested } \\
\text { blindly }\end{array}$ & $\begin{array}{l}\mathrm{N}=381 \text { (478 serum } \\
\text { samples) } \\
\mathrm{n}_{\text {cases }}=5 \\
\mathrm{n}_{\text {family }}=28 \\
\mathrm{n}_{\text {culler }}=95 \\
\mathrm{n}_{\text {asymp contact }}=75 \\
\mathrm{n}_{\text {no contact }}=81 \\
\text { Individuals } \\
\text { affected by } \\
\text { outbreak: } \\
\text { Surviving cases, } \\
\text { family members } \\
\text { exposed to cases } \\
\text { during infectious } \\
\text { period, } \\
\text { individuals } \\
\text { involved with } \\
\text { culling, } \\
\text { asymptomatic } \\
\text { individuals who } \\
\text { contacted } \\
\text { diseased chickens } \\
\text { in areas with } \\
\text { cases, individuals } \\
\text { with no known } \\
\text { contact with } \\
\text { diseased } \\
\text { chickens, } \\
\text { asymptomatic } \\
\text { health care } \\
\text { workers (HCWs) in } \\
\text { contact with cases } \\
\text { Turkey, } \\
\text { Feb } 2006\end{array}$ & $\begin{array}{l}\text { Avian } \\
\text { A/Turkey/ } \\
\text { 13/06 (H5N1) } \\
\text { A/Turkey/ } \\
\text { Turkey/1/2005 } \\
\text { (H5N1) }\end{array}$ & $\begin{array}{l}\text { ELISA (positive if } \\
\text { absorbance } \geq 620 \mathrm{~nm} \text { ); HI } \\
\text { assay (positive if } \geq 20 \text { ); MN } \\
\text { (positive if titre } \geq 10 \text { ) used } \\
\text { on samples with } \\
\text { antibodies from ELISA or } \\
\mathrm{HI} \text {, and to test a random } \\
\text { sample of negative HI } \\
\text { assays } \\
\text { Only cases had symptoms } \\
\text { suggestive of avian } \\
\text { influenza } \\
4 \text { samples found positive } \\
\text { by MN ( } 3 \text { cases, } 1 \text { family } \\
\text { member) }\end{array}$ & $\|-3$ & $\begin{array}{l}\text { Fair } \\
\text { Laboratory } \\
\text { methods not } \\
\text { standardized }\end{array}$ \\
\hline
\end{tabular}




\begin{tabular}{|c|c|c|c|c|c|c|}
\hline \multicolumn{7}{|c|}{ INDIVIDUALS WITH OCCUPATIONAL EXPOSURE TO AVIAN POPULATIONS } \\
\hline Study & Study Design & Participants & Influenza type & Key findings & Level & Quality \\
\hline Dejpichai R (2009) $)^{42}$ & $\begin{array}{l}\text { Cross-sectional } \\
\text { seroprevalence } \\
\text { survey }\end{array}$ & $\begin{array}{l}\mathrm{N}=901 \\
\text { Rural villages } \\
\text { where backyard } \\
\text { farming is } \\
\text { common but have } \\
\text { no live poultry } \\
\text { markets } \\
\text { Thailand, Oct } \\
2005\end{array}$ & $\begin{array}{l}\text { Avian } \\
\text { A/Thailand/ } \\
1(\text { KAN-1)/2004 } \\
\text { (H5N1) }\end{array}$ & $\begin{array}{l}\text { MN assay (positive if titres } \\
\geq 40 \text { ) confirmed with } \\
\text { confirmatory } \\
\text { immunoflourescence assay } \\
68.1 \% \text { of participants } \\
\text { reported direct or close } \\
\text { contact with backyard } \\
\text { poultry } \\
110 \text { participants reported a } \\
\text { history of acute respiratory } \\
\text { illness: } 74.5 \% \text { reported } \\
\text { direct or close contact with } \\
\text { backyard poultry, } 31.8 \% \\
\text { reported direct or close } \\
\text { contact with sick or dead } \\
\text { poultry, } 13.6 \% \text { reported } \\
\text { close contact with a } \\
\text { person with confirmed } \\
\text { H5N1 infection } \\
\text { All participants were } \\
\text { seronegative for H5N1 } \\
\text { neutralizing antibodies }\end{array}$ & III & $\begin{array}{l}\text { Fair } \\
\text { Potential for } \\
\text { recall bias as } \\
\text { survey was } \\
\text { conducted for } \\
\text { an outbreak } \\
\text { that occurred in } \\
2004\end{array}$ \\
\hline $\begin{array}{l}\text { Du Ry van Beest } \\
\text { Holle, M. }(2005)^{22}\end{array}$ & $\begin{array}{l}\text { Survey with } \\
\text { serological } \\
\text { testing }\end{array}$ & $\begin{array}{l}\mathrm{N}=62 \text { (with } 25 \mathrm{~A} / \\
\text { H7N7 index } \\
\text { cases) } \\
\text { Household } \\
\text { members who } \\
\text { were exposed to } \\
\text { confirmed A/ } \\
\text { H7N7 index cases } \\
\text { (infected poultry } \\
\text { workers); People } \\
\text { living on poultry } \\
\text { farms or keeping } \\
\text { backyard poultry } \\
\text { were excluded } \\
\text { Netherlands, } 2003\end{array}$ & $\begin{array}{l}\text { Avian } \\
\text { A/H7N7 }\end{array}$ & $\begin{array}{l}\mathrm{HI} \text { assay (positive if titres } \\
\geq 1: 10 \text { ) at least } 3 \text { weeks } \\
\text { after diagnosis of primary } \\
\text { case in the household, } \\
\text { single sample } \\
8 \text { people (12.9\%) reported } \\
\text { health complaints ( } 2 \text { met } \\
\text { case definition for } \\
\text { conjunctivitis only, } 4 \text { met } \\
\text { case definition of ILI only, } \\
\text { and } 2 \text { met both definitions) } \\
56 / 62 \text { provided serum } \\
\text { samples and } 33 \text { (58.9\%) } \\
\text { had detectable antibodies } \\
\text { against } \mathrm{H} 7 \\
\text { Of } 24 \text { households } \\
\text { serologically tested, } 15 \\
\text { (62.5\%) had one or more } \\
\text { household contacts with } \\
\text { detectable H7 antibodies } \\
\mathrm{HI} \text { antibodies against } \mathrm{A} / \\
\mathrm{H} 7, \mathrm{~A} / \mathrm{H} 1 \text {, and } \mathrm{A} / \mathrm{H} 3 \text { were } \\
\text { not cross reactive with the } \\
\text { heterologous virus; } \\
\text { Neutralisation of A/H7N7 } \\
\text { not demonstrated in } \mathrm{MN}\end{array}$ & III & $\begin{array}{l}\text { Fair } \\
\text { High non- } \\
\text { response rate } \\
\text { (26.4\% of } \\
\text { households) } \\
\text { with no analysis } \\
\text { done to } \\
\text { compare } \\
\text { responding vs. } \\
\text { non-responding } \\
\text { households }\end{array}$ \\
\hline
\end{tabular}




\begin{tabular}{|c|c|c|c|c|c|c|}
\hline \multicolumn{7}{|c|}{ INDIVIDUALS WITH OCCUPATIONAL EXPOSURE TO AVIAN POPULATIONS } \\
\hline Study & Study Design & Participants & Influenza type & Key findings & Level & Quality \\
\hline Gray GC (2008) $)^{43}$ & $\begin{array}{l}\text { Longitudinal } \\
\text { survey with } \\
\text { serological } \\
\text { testing (at } \\
\text { baseline, } 12 \text { and } \\
24 \text { months) }\end{array}$ & $\begin{array}{l}\mathrm{N}=798 \\
\mathrm{n}_{\text {exposed }}=372 \\
\mathrm{n}_{\text {unexposed spouses }}=368 \\
\mathrm{n}_{\text {control }}=66 \\
\text { Rural agriculture } \\
\text { workers exposed } \\
\text { to poultry; } \\
\text { unexposed } \\
\text { spouses; } \\
\text { university controls } \\
\text { USA, 2004-2006 }\end{array}$ & $\begin{array}{l}\text { Human } \\
\text { A/New } \\
\text { Caledonia/20/99 } \\
\text { (H1N1) } \\
\text { A/Nanchang/933/95 } \\
\text { (H3N2) } \\
\text { A/Panama/2007/99 } \\
\text { (H3N2) } \\
\text { Avian } \\
\text { A/Duck/Cz/1/56 } \\
\text { (H4N6) } \\
\text { A/Chucker/ } \\
\text { MN/14591-7/98 } \\
\text { (H5N2) } \\
\text { A/Turkey/MA/65 } \\
\text { (H6N2) } \\
\text { A/Turkey/ } \\
\text { VA/4529/02 (H7N2) } \\
\text { A/Turkey/ } \\
\text { MN/38391-6/95 } \\
\text { (H9N2) }\end{array}$ & 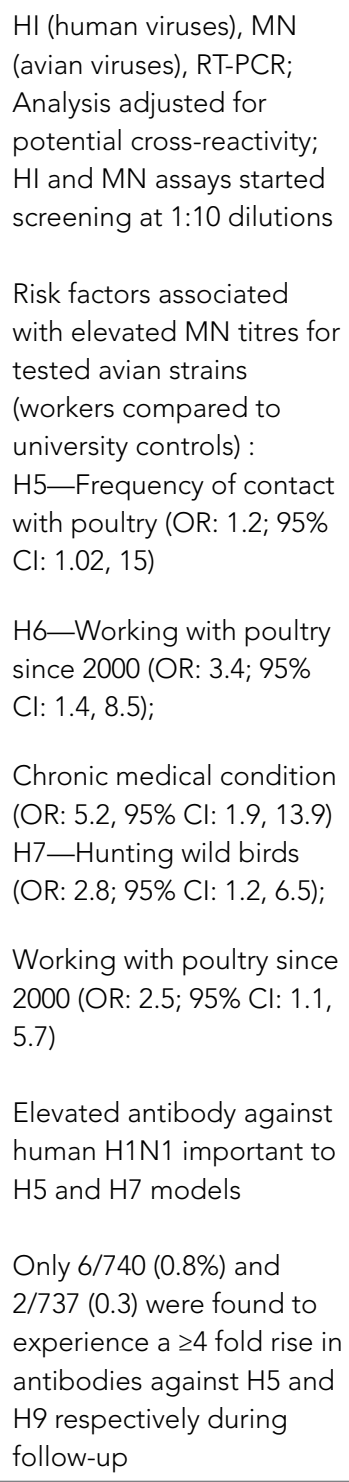 & $\|-2$ & $\begin{array}{l}\text { Poor } \\
\text { Control group } \\
\text { of university } \\
\text { participants not } \\
\text { adequately } \\
\text { matched } \\
\text { (younger than } \\
\text { exposed) } \\
\text { Potential biases } \\
\text { could be } \\
\text { introduced by } \\
\text { voluntary } \\
\text { participation, } \\
\text { self-reporting of } \\
\text { exposure, } \\
\text { potential } \\
\text { mis-matching } \\
\text { between study } \\
\text { and circulating } \\
\text { viruses, } \\
\text { cross-reacting } \\
\text { antibodies } \\
\text { unaccounted for }\end{array}$ \\
\hline
\end{tabular}




\begin{tabular}{|c|c|c|c|c|c|c|}
\hline \multicolumn{7}{|c|}{ INDIVIDUALS WITH OCCUPATIONAL EXPOSURE TO AVIAN POPULATIONS } \\
\hline Study & Study Design & Participants & Influenza type & Key findings & Level & Quality \\
\hline Gray GC (2011) $)^{18}$ & $\begin{array}{l}\text { Cross-sectional } \\
\text { seroprevalence, } \\
\text { age-group } \\
\text { matched } \\
\text { controls }\end{array}$ & $\begin{array}{l}\mathrm{N}=235 \\
\mathrm{n}_{\text {exposed }}=157 \\
\mathrm{n}_{\text {control }}=78 \\
\text { Registered bird } \\
\text { banders > 18 } \\
\text { years of age } \\
\text { and active } \\
\text { within the last } \\
12 \text { months; } \\
\text { University } \\
\text { controls } \\
\text { USA, 2009/10 }\end{array}$ & $\begin{array}{l}\text { Human } \\
4 \text { strains } \\
\text { Avian } \\
8 \text { strains }\end{array}$ & $\begin{array}{l}\text { HI (human samples; } \\
\text { elevated titres considered } \\
\text { at } \geq 1: 40 \text { ), MN (avian } \\
\text { samples; elevated titres } \\
\text { considered at } \geq 1: 10 \text { ), } \\
\text { RT-PCR } \\
\text { Sera collected from } 127 \\
(81 \%) \text { bird banders and } 69 \\
(88 \%) \text { controls } \\
3 \text { bird banders and } 1 \\
\text { control had elevated titre } \\
\text { against H7N3, H9N2, or } \\
\text { H11N3 (AIVs); Bird banders } \\
\text { reported banding wild } \\
\text { raptors } \\
15 \% \text { of bird banders } \\
\text { reported wearing gloves, } \\
36 \% \text { used eye protection } \\
\text { and } 78 \% \text { washed their } \\
\text { hands often or always }\end{array}$ & III & $\begin{array}{l}\text { Fair } \\
\text { Groups not } \\
\text { completely } \\
\text { comparable; } \\
\text { Mismatched } \\
\text { strains could } \\
\text { generate falsely } \\
\text { positive results }\end{array}$ \\
\hline Hinjoy S (2008) $)^{44}$ & $\begin{array}{l}\text { Cross-sectional } \\
\text { seroprevalence } \\
\text { survey }\end{array}$ & $\begin{array}{l}\mathrm{N}=322 \\
\text { Poultry farmers } \\
\text { Thailand, } 2004\end{array}$ & $\begin{array}{l}\text { Avian } \\
\text { H5N1 }\end{array}$ & $\begin{array}{l}\text { MN (positive if } \geq 80 \text { with } \\
\text { confirmatory ELISA or } \\
\text { Western blot) } \\
\text { No participant was found } \\
\text { positive based on cut-off, } \\
\text { but } 7 \text { ( } 2.2 \% \text { ) had lower } \\
\text { reactive antibody titres } \\
\text { ( } 4 \text { had titres of } 10,2 \text { had } \\
\text { titres of } 20 \text { and } 1 \text { had titres } \\
\text { of } 40 \text { ) }\end{array}$ & III & $\begin{array}{l}\text { Fair } \\
\text { Voluntary } \\
\text { participation, } \\
\text { not comparative } \\
\text { analysis done } \\
\text { between } \\
\text { responders and } \\
\text { non-responders }\end{array}$ \\
\hline $\begin{array}{l}\text { Du Ry van Beest } \\
\text { Holle, M. (2010) }\end{array}$ & $\begin{array}{l}\text { Cross-sectional } \\
\text { seroprevalence } \\
\text { survey (single } \\
\text { serum sample) }\end{array}$ & $\begin{array}{l}\mathrm{N}=495 \\
\text { Persons working } \\
\text { or living on } 12 \\
\text { farms from } \\
\text { another vaccine } \\
\text { effectiveness } \\
\text { study } \\
\text { Indonesia, } \\
\text { Jan-Feb } 2007\end{array}$ & $\begin{array}{l}\text { Avian } \\
\text { A/Ck/Banten/05- } \\
\text { 1116/05 (H5N1) } \\
\text { A/H5N1/Indo/05/ } \\
\text { IBCDC-RG }\end{array}$ & $\begin{array}{l}\text { HI (positive: titre } \geq 160 \text { with } \\
2 \text { independent tests), MN } \\
\text { (positive: titre } \geq 80 \text { with } 2 \\
\text { independent tests) } \\
\text { One farm experienced an } \\
\text { outbreak, but no evidence } \\
\text { of antibodies against A/ } \\
\text { H5N1 was detected } \\
1 \text { individual had a titre of } \\
20 \text { (HI assay), which was } \\
\text { inconclusive } \\
55 \text { (11\%) complained of } \\
\text { fever and cough in the } \\
\text { past six months; } 17 \text { (3\%) } \\
\text { reported ILI, with one case } \\
\text { exposed to unusual deaths } \\
\text { in poultry on the farm }\end{array}$ & III & $\begin{array}{l}\text { Fair } \\
\text { Voluntary } \\
\text { participation, } \\
\text { not comparative } \\
\text { analysis done } \\
\text { between } \\
\text { responders and } \\
\text { non-responders }\end{array}$ \\
\hline
\end{tabular}




\begin{tabular}{|c|c|c|c|c|c|c|}
\hline \multicolumn{7}{|c|}{ INDIVIDUALS WITH OCCUPATIONAL EXPOSURE TO AVIAN POPULATIONS } \\
\hline Study & Study Design & Participants & Influenza type & Key findings & Level & Quality \\
\hline Huo X $(2012)^{46}$ & $\begin{array}{l}\text { Cross-sectional } \\
\text { seroprevalence } \\
\text { survey (single } \\
\text { serum sample) }\end{array}$ & $\begin{array}{l}\mathrm{N}=306 \\
\text { Poultry workers } \\
\text { from backyard } \\
\text { poultry farms } \\
\text { China, Jul-Aug } \\
2010\end{array}$ & $\begin{array}{l}\text { Avian } \\
\text { A/Anhui/1/05 } \\
\text { A/Hubei/1/10 }\end{array}$ & $\begin{array}{l}\mathrm{HI} \text { (horse RBC, positive: } \\
\text { titre } \geq 1: 160 \text { ) } \\
\text { Overall seropositive rate } \\
\text { for } \mathrm{H} 5 \mathrm{~N} 1: 2.61 \% \text { ( } 95 \% \mathrm{Cl} \text { : } \\
1.14,5.09 \text { ) } \\
\text { Seropositive rates were } \\
\text { significantly correlated } \\
\text { with the medians of } \\
\text { increasing poultry number } \\
\text { per flock } \\
\text { Poultry number per flock } \\
\text { was associated with } 2.39 \\
\text { (95\% Cl: } 1.00,5.69 \text { ) } \\
\text { increased risk for } \\
\text { seropositive poultry } \\
\text { workers adjusted for age } \\
\text { and sex }\end{array}$ & III & $\begin{array}{l}\text { Fair } \\
\text { Cross-reactivity } \\
\text { not considered }\end{array}$ \\
\hline Jia N (2009) ${ }^{47}$ & $\begin{array}{l}\text { Cross-sectional } \\
\text { seroprevalence } \\
\text { (single serum } \\
\text { sample) }\end{array}$ & $\begin{array}{l}\mathrm{N}=1467 \\
\text { Farmers and } \\
\text { poultry workers in } \\
\text { rural villages } \\
\text { China, Apr } 2006\end{array}$ & $\begin{array}{l}\text { Avian } \\
\text { A/African Starling/ } \\
\text { England-Q/938/79 } \\
\text { (H7N1) } \\
\text { A/Chicken/ } \\
\text { Shanghai/10/01 } \\
\text { (H9N2) }\end{array}$ & $\begin{array}{l}\text { HI (horse RBC, positive: } \\
\text { titre } \geq 1: 160 \text { ) } \\
12 \text { samples were positive } \\
\text { for } \mathrm{H} 9 \text {, none were positive } \\
\text { for } \mathrm{H} 7 \\
\text { No significant association } \\
\text { between } \mathrm{H} 9 \text { response and } \\
\text { exposure to dead or ill } \\
\text { poultry, but } 3 / 4 \text { subjects } \\
\text { with highest } \mathrm{H} 9 \text { titres } \\
\text { (>1:320) reported } \\
\text { exposure to dead or ill } \\
\text { poultry at home }\end{array}$ & III & $\begin{array}{l}\text { Fair } \\
\text { No standard for } \\
\mathrm{HI} \text { for } \mathrm{H} 7 \text { or } \mathrm{H} 9 \text {, } \\
\text { so } \mathrm{WHO} \text { criteria } \\
\text { for } \mathrm{H} 5 \mathrm{~N} 1 \text { was } \\
\text { used; Only HI } \\
\text { used as a } \\
\text { serology test; } \\
\text { Cross reactivity } \\
\text { not accounted } \\
\text { for in analysis }\end{array}$ \\
\hline
\end{tabular}




\begin{tabular}{|c|c|c|c|c|c|c|}
\hline \multicolumn{7}{|c|}{ INDIVIDUALS WITH OCCUPATIONAL EXPOSURE TO AVIAN POPULATIONS } \\
\hline Study & Study Design & Participants & Influenza type & Key findings & Level & Quality \\
\hline Kayali G (2010) $)^{48}$ & $\begin{array}{l}\text { Cross-sectional } \\
\text { seroprevalence } \\
\text { survey (single } \\
\text { serum sample) }\end{array}$ & $\begin{array}{l}\mathrm{N}=177 \\
\mathrm{n}_{\text {grower }}=57 \\
\mathrm{n}_{\text {worker }}=38 \\
\mathrm{n}_{\text {control }}=82 \\
\text { Turkey growers } \\
\text { (backyard and } \\
\text { confinement), } \\
\text { turkey meat } \\
\text { processing plant } \\
\text { workers; } \\
\text { Unexposed } \\
\text { controls } \\
\text { USA, Mar 2007- } \\
\text { Apr 2008 }\end{array}$ & $\begin{array}{l}\text { Human } \\
\text { A/New } \\
\text { Caledonia/20/99 } \\
\text { (H1N1) } \\
\text { A/Panama/2007/99 } \\
\text { (H3N2) } \\
\text { Avian } \\
\text { H4N6 } \\
\text { H5N2 } \\
\text { H6N2 } \\
\text { H7N2 } \\
\text { H8N4 } \\
\text { H9N2 } \\
\text { H11N9 }\end{array}$ & $\begin{array}{l}\text { MN (positive at } \geq 1: 10 \\
\text { dilutions, tested in } \\
\text { duplicate), HI (guinea pig, } \\
\text { positive at } \geq 1: 40 \text {, testing } \\
\text { for cross-reactivity) } \\
\text { 14/95 (15\%) exposed had } \\
\text { elevated antibody titres } \\
\text { against any AIV compared } \\
\text { to } 7 / 82 \text { (8.2\%) of controls } \\
\text { Titres against H5 were } \\
\text { higher for growers } \\
\text { compared to control } \\
\text { (p=.003); when adjusted } \\
\text { for H3N2 OR: } 4.5 \text { ( } 95 \% \text { Cl: } \\
\text { 1.5, } 13.3 \text { ) for being } \\
\text { seropositive for H5 } \\
\text { No difference in titres for } \\
\text { H7 and H11 between } \\
\text { groups, but growers } \\
\text { (especially small scale) had } \\
\text { elevated titres for all other } \\
\text { tested subtypes } \\
\text { Potential risk factors such } \\
\text { as age, gender, smoking, } \\
\text { chronic diseases, ILI, use of } \\
\text { PPE were not associated } \\
\text { with serological outcomes }\end{array}$ & III & $\begin{array}{l}\text { Fair } \\
\text { Small numbers; } \\
\text { Used low } \\
\text { thresholds for } \\
\text { assays; Potential } \\
\text { for cross- } \\
\text { reactivity } \\
\text { between AIVs }\end{array}$ \\
\hline Kayali G $(2011)^{49}$ & $\begin{array}{l}\text { Cross-sectional } \\
\text { seroprevalence } \\
\text { (single serum } \\
\text { sample) }\end{array}$ & $\begin{array}{l}\mathrm{N}=250 \\
\mathrm{n}_{\text {backyard }}=128 \\
\mathrm{n}_{\text {commercial }}=72 \\
\mathrm{n}_{\text {control }}=50 \\
\text { Chicken growers } \\
\text { (backyard and } \\
\text { commercial); } \\
\text { Urban controls } \\
\text { (not exposed to } \\
\text { poultry, voluntary) } \\
\text { Lebanon, } \\
\text { Jul-Sep } 2010\end{array}$ & $\begin{array}{l}\text { Human } \\
\text { A/Brisbane/59/04 } \\
\text { (H1N1) } \\
\text { A/California/04/09 } \\
\text { (H1N1) } \\
\text { A/Brisbane/10/07 } \\
\text { (H3N2) } \\
\text { Avian } \\
\text { Subtypes H4-H16 }\end{array}$ & $\begin{array}{l}\text { MN (positive at } \geq 1: 10 \\
\text { dilutions, tested in } \\
\text { duplicate), HI (horse RBC, } \\
\text { testing positive MN } \\
\text { samples and for cross- } \\
\text { reactivity) } \\
\text { Control group had higher } \\
\text { titres for seasonal and } \\
\text { pandemic } \mathrm{H} 1 \mathrm{~N} 1 \text {, but } \\
\text { groups were similar for } \\
\text { H3N2 } \\
5 \text { backyard growers tested } \\
\text { positive with both MN and } \\
\text { HI (3 for H4 and } 2 \text { for H11) } \\
\text { Commercial growers more } \\
\text { likely to use protective } \\
\text { equipment }\end{array}$ & III & $\begin{array}{l}\text { Fair } \\
\text { Groups not } \\
\text { completely } \\
\text { comparable }\end{array}$ \\
\hline
\end{tabular}




\begin{tabular}{|c|c|c|c|c|c|c|}
\hline \multicolumn{7}{|c|}{ INDIVIDUALS WITH OCCUPATIONAL EXPOSURE TO AVIAN POPULATIONS } \\
\hline Study & Study Design & Participants & Influenza type & Key findings & Level & Quality \\
\hline $\begin{array}{l}\text { Khuntirat BP } \\
(2011)^{50}\end{array}$ & $\begin{array}{l}\text { Cross-sectional } \\
\text { seroprevalence }\end{array}$ & $\begin{array}{l}\mathrm{N}=800 \\
\text { Villagers } \geq 20 \\
\text { years of age from } \\
\text { rural areas of } \\
\text { Thailand affected } \\
\text { by highly } \\
\text { pathogenic avian } \\
\text { influenza (most } \\
\text { villagers raise } \\
\text { small flocks of } \\
\text { domestic poultry } \\
\text { e.g. chicken, } \\
\text { ducks, quail) } \\
\text { Thailand, } \\
\text { Apr-Oct } 2008\end{array}$ & $\begin{array}{l}8 \text { Human strains } \\
\text { (H1N1, H3N2, } \\
\text { H5N1, H9N2) } \\
\text { 16 Avian strains } \\
\text { (H1N1, H2N2, } \\
\text { H4N6, H5N2, H6N1, } \\
\text { H6N2, H7N2, H7N7, } \\
\text { H8N4, H9N2, } \\
\text { H10N4, H10N7, } \\
\text { H11N9, H12N5) } \\
\text { 2 Swine strains } \\
\text { (H1N1, H3N2) }\end{array}$ & 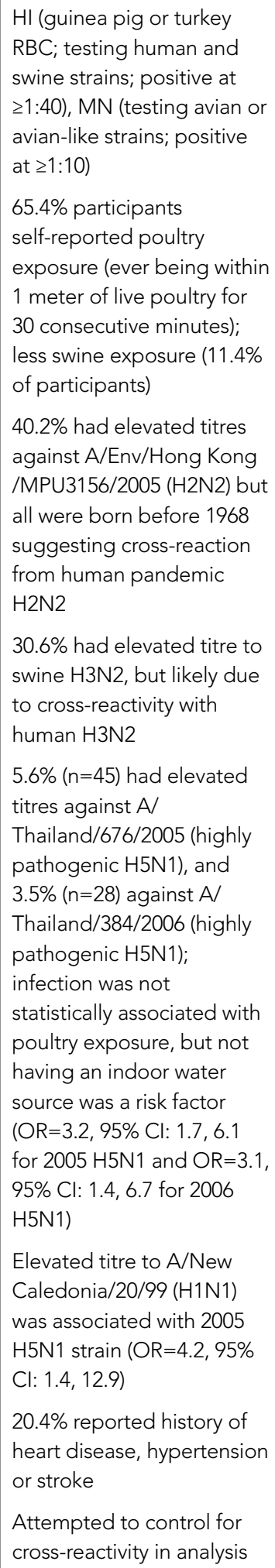 & III & Good \\
\hline
\end{tabular}




\begin{tabular}{|c|c|c|c|c|c|c|}
\hline \multicolumn{7}{|c|}{ INDIVIDUALS WITH OCCUPATIONAL EXPOSURE TO AVIAN POPULATIONS } \\
\hline Study & Study Design & Participants & Influenza type & Key findings & Level & Quality \\
\hline $\begin{array}{l}\text { Koopmans M } \\
(2004)^{51}\end{array}$ & $\begin{array}{l}\text { Descriptive } \\
\text { (Outbreak } \\
\text { surveillance) }\end{array}$ & $\begin{array}{l}\text { Population wide } \\
\mathrm{N}=453 \text { cases } \\
\text { reported } \\
\text { People who had } \\
\text { direct contact } \\
\text { with poultry or } \\
\text { poultry products } \\
\text { that could have } \\
\text { been infected } \\
\text { with H7, or had } \\
\text { close contact with } \\
\text { an H7-infected } \\
\text { person } \\
\text { Netherlands, } 2003\end{array}$ & $\begin{array}{l}\text { Avian } \\
\mathrm{H} 7\end{array}$ & $\begin{array}{l}\text { RT-PCR, HI (turkey RBC; } \\
\text { used to type and subtype } \\
\text { influenza strains) } \\
\text { Most H7 cases detected in } \\
\text { poultry cullers (54/131) } \\
\text { Attack rate of } \\
\text { conjunctivitis = } 7.8 \% \\
\text { Attack rate of ILI = } 2 \% \\
3 \text { contacts of primary cases } \\
\text { had confirmed A/H7 } \\
\text { infection, all shared } \\
\text { household with a poultry } \\
\text { worker or farmer } \\
\text { Of contacts of primary } \\
\text { cases, conjunctivitis was } \\
\text { reported by } 70 \text { people, } 13 \\
\text { for ILI, and } 14 \text { for other } \\
\text { illness } \\
\text { ILI was reported less often } \\
\text { by A/H7 positive cases } \\
\text { than people who tested } \\
\text { negative } \\
\text { Samples positive for A/H7 } \\
\text { were highest in first } 4 \text { days } \\
\text { of illness onset }\end{array}$ & III & Good \\
\hline Kwon D (2012) $)^{15}$ & $\begin{array}{l}\text { Descriptive } \\
\text { (Outbreak } \\
\text { surveillance with } \\
\text { serologic } \\
\text { testing—single } \\
\text { samples from } \\
1576 \text { individuals, } \\
\text { paired samples } \\
\text { from 936) }\end{array}$ & $\begin{array}{l}\mathrm{N}=2512 \text { (3448 } \\
\text { samples) } \\
\text { Persons working } \\
\text { on poultry farms } \\
\text { or culled birds } \\
\text { during the } \\
2003-04 \\
\text { outbreaks } \\
\text { South Korea, } \\
2003 / 04\end{array}$ & $\begin{array}{l}\text { Avian } \\
\text { H5N1 }\end{array}$ & $\begin{array}{l}\text { MN (positive if }>80 \text {, at } \\
\text { least } 2 \text { independent } \\
\text { assays) with confirmatory } \\
\text { testing with } \mathrm{HI} \text { (horse) or } \\
\text { H5-specific Western blot } \\
9 \mathrm{MN} \text { positive cases (4 } \\
\text { single sample, } 5 \text { paired } \\
\text { samples); } 2 \text { positive by HI, } \\
\text { but all } 9 \text { positive by } \\
\text { Western blot; All cullers }\end{array}$ & III & $\begin{array}{l}\text { Good } \\
\text { Cross-reactivity } \\
\text { not assessed } \\
\text { due to limited } \\
\text { serum sample }\end{array}$ \\
\hline
\end{tabular}




\begin{tabular}{|c|c|c|c|c|c|c|}
\hline \multicolumn{7}{|c|}{ INDIVIDUALS WITH OCCUPATIONAL EXPOSURE TO AVIAN POPULATIONS } \\
\hline Study & Study Design & Participants & Influenza type & Key findings & Level & Quality \\
\hline Leibler JH (2011) 52 & $\begin{array}{l}\text { Cross-sectional } \\
\text { seroprevalence } \\
\text { (2 time points) }\end{array}$ & $\begin{array}{l}\mathrm{N}=99 \\
\mathrm{n}_{\text {workers }}=24 \\
\mathrm{n}_{\text {control }}=75 \\
\text { Convenience } \\
\text { sample of poultry } \\
\text { workers and } \\
\text { community } \\
\text { residents } \\
\text { USA, 2003, } 2005\end{array}$ & $\begin{array}{l}\text { Human } \\
\text { A/New } \\
\text { Caledonia/20/99 } \\
\text { (H1N1) } \\
\text { A/Panama/2007/99 } \\
\text { (H3N2) } \\
\text { Avian } \\
\text { A/Duck/Cz/1/56 } \\
\text { (H4N6) } \\
\text { A/Chucker/ } \\
\text { MN/14591-7/98 } \\
\text { (H5N2) } \\
\text { A/Turkey/MA/65 } \\
\text { (H6N2) } \\
\text { A/Turkey/ } \\
\text { VA/4529/02 (H7N2) } \\
\text { A/Turkey/ } \\
\text { MN/38391-6/95 } \\
\text { (H9N2) } \\
\text { A/Chicken/DE/04 } \\
\text { (H7N2) }\end{array}$ & $\begin{array}{l}\text { HI (guinea pig), MN } \\
\text { (screened at 1:10 dilution) } \\
\text { No evidence of infection } \\
\text { with any AIVs found } \\
\text { High prevalence of H1N1 } \\
\text { and H3N2 in both poultry } \\
\text { workers and community } \\
\text { members }\end{array}$ & II-3 & $\begin{array}{l}\text { Fair } \\
\text { Convenience } \\
\text { sample may } \\
\text { have missed } \\
\text { individuals who } \\
\text { were affected } \\
\text { by avian } \\
\text { influenza } \\
\text { outbreak in } \\
2004\end{array}$ \\
\hline
\end{tabular}




\begin{tabular}{|c|c|c|c|c|c|c|}
\hline \multicolumn{7}{|c|}{ INDIVIDUALS WITH OCCUPATIONAL EXPOSURE TO AVIAN POPULATIONS } \\
\hline Study & Study Design & Participants & Influenza type & Key findings & Level & Quality \\
\hline Lu $(2008)^{53}$ & $\begin{array}{l}\text { Cross-sectional } \\
\text { seroprevalence } \\
\text { (positive H5N1 } \\
\text { cases were } \\
\text { followed up for } \\
1 \text { year) }\end{array}$ & $\begin{array}{l}\mathrm{N}=1214 \\
\mathrm{n}_{\text {occupational }}=231 \\
\mathrm{n}_{\text {general }}=983 \\
\text { Occupationally } \\
\text { exposed (raising, } \\
\text { selling and } \\
\text { slaughtering of } \\
\text { chickens and } \\
\text { ducks), and } \\
\text { general } \\
\text { population (not } \\
\text { engaged in } \\
\text { activities handling } \\
\text { live chickens or } \\
\text { ducks) randomly } \\
\text { selected from } \\
\text { three of nine } \\
\text { regions affected } \\
\text { by H5N1 } \\
\text { outbreaks } \\
\text { China, } \\
\text { Apr-Jun } 2004\end{array}$ & $\begin{array}{l}\text { Human } \\
\text { A/New } \\
\text { Caledonia/20/99 } \\
\text { (H1N1) } \\
\text { A/Panama/2007/99 } \\
\text { (H3N2) } \\
\text { Avian } \\
\text { A/goose/ } \\
\text { Guangdong/1/96 } \\
\text { (H5N1) } \\
\text { A/African/starling/ } \\
\text { Englan-q/983/79 } \\
\text { (H7N7) } \\
\text { A/chicken/ } \\
\text { Shanghi/10/01 } \\
\text { (H9N2) }\end{array}$ & $\begin{array}{l}\text { HI (chicken RBC, used for } \\
\text { detecting all strains; } \\
\text { positive if titres } \geq 1: 20 \text { ), } \\
\text { MN used to verify a } \\
\text { sample of positive HI } \\
\text { results (positive if titres } \\
\geq 1: 20 \text { ) } \\
\text { Positive results by HI: } \\
\text { H1N1-31.22\% ( } n=379 \text { ) } \\
\text { H3N2-71.75\% ( } n=871 \text { ) } \\
\text { H5N1-2.47\% ( }=30 \text { ) } \\
\text { H7N7-0.08\% ( } n=1 \text { ) } \\
\text { H9N2-4.86\% ( } n=59 \text { ) } \\
1 \text { case of H5N1 was still } \\
\text { positive one year later } \\
\text { (titre } 1: 40 \text { ), while all other } \\
\text { positive avian cases } \\
\text { became negative } \\
\text { Positive rate in } \\
\text { occupationally exposed } \\
\text { was slightly higher for } \\
\text { H5N1 (3.03\% vs. } 2.34 \% \text {, } \\
\text { p }>.05 \text { ), higher for H9N2 } \\
\text { ( } 9.52 \% \text { vs. } 3.76 \%, ~ p<.01 \text {, } \\
\text { and had the single H7N7 } \\
\text { positive case } \\
\text { MN assay results were } \\
\text { positively correlated with } \\
\text { the HI assay results }\end{array}$ & $\|-3$ & $\begin{array}{l}\text { Good } \\
\text { Cross-reactivity } \\
\text { not considered }\end{array}$ \\
\hline Ogata T $(2008)^{54}$ & $\begin{array}{l}\text { Cross-sectional } \\
\text { serology (paired } \\
\text { sera at least } 4 \\
\text { weeks and up to } \\
2 \text { months apart) }\end{array}$ & $\begin{array}{l}\mathrm{N}=257 \\
\text { Poultry workers } \\
\text { from H5N2- } \\
\text { positive chicken } \\
\text { farms } \\
\text { Japan, } \\
\text { Jun-Nov } 2005\end{array}$ & $\begin{array}{l}\text { Avian } \\
\text { A/Chicken/ } \\
\text { lbaraki/1/2005 } \\
\text { (H5N2) }\end{array}$ & $\begin{array}{l}\text { MN (positive if titre 1:40 or } \\
\text { greater in paired sera) } \\
\text { Adjusted OR for H5N2 } \\
\text { positivity in workers over } \\
40 \text { years of age: } 4.6 \text { ( } 95 \% \\
\mathrm{Cl} \text { : } 1.6,13.7 \text { ) } \\
\text { Adjusted OR for H5N2 } \\
\text { positivity in workers with a } \\
\text { history of seasonal } \\
\text { influenza vaccination: } 3.1 \\
\text { (95\% Cl: } 1.6,6.1 \text { ) } \\
\text { Adjusted for sex, age, } \\
\text { number of workers on the } \\
\text { farm and/or history of } \\
\text { seasonal influenza } \\
\text { vaccination }\end{array}$ & $\|-3$ & $\begin{array}{l}\text { Fair } \\
\text { Time of } \\
\text { infection of the } \\
\text { farm poultry } \\
\text { was unknown; } \\
17 \% \text { of } \\
\text { participants } \\
\text { excluded from } \\
\text { analysis due to } \\
\text { missing data; } \\
\text { Use of MN test } \\
\text { only may have } \\
\text { been insufficient }\end{array}$ \\
\hline
\end{tabular}




\begin{tabular}{|c|c|c|c|c|c|c|}
\hline \multicolumn{7}{|c|}{ INDIVIDUALS WITH OCCUPATIONAL EXPOSURE TO AVIAN POPULATIONS } \\
\hline Study & Study Design & Participants & Influenza type & Key findings & Level & Quality \\
\hline Ortiz EJ $(2007)^{55}$ & $\begin{array}{l}\text { Cross-sectional } \\
\text { seroprevalence } \\
\text { (single serum } \\
\text { sample) }\end{array}$ & $\begin{array}{l}\mathrm{N}=150 \\
\mathrm{n}_{\text {exposed }}=133 \\
\mathrm{n}_{\text {unexposed }}=17 \\
\text { Poultry farm } \\
\text { workers } \\
\text { Peru, } 2006\end{array}$ & $\begin{array}{l}\text { Human } \\
\text { A/New } \\
\text { Caledonia/20/99 } \\
\text { (H1N1) } \\
\text { A/Nanchang/933/95 } \\
\text { (H3N2) } \\
\text { A/Panama/2007/99 } \\
\text { (H3N2) } \\
\text { Avian } \\
9 \text { subtypes H4-H12 }\end{array}$ & $\begin{array}{l}\mathrm{HI} \text { (guinea pig RBC) to } \\
\text { assess cross-reactivity } \\
\text { (dilutions began at 1:10), } \\
\text { MN (positive at } \geq 1: 80 \text { ) } \\
\text { Prevalence of AIV low in } \\
\text { both groups } \\
\text { One poultry-exposed } \\
\text { subject had a 1:10 titre } \\
\text { against avian } \mathrm{H} 5 \text { and } \\
\text { another worker against } \\
\text { avian } \mathrm{H} 12\end{array}$ & III & $\begin{array}{l}\text { Good } \\
\text { Study farm had } \\
\text { good active } \\
\text { surveillance } \\
\text { program to } \\
\text { corroborate } \\
\text { findings }\end{array}$ \\
\hline Ortiz JR $(2007)^{56}$ & $\begin{array}{l}\text { Descriptive } \\
\text { seroprevalence } \\
\text { survey }\end{array}$ & $\begin{array}{l}\mathrm{N}=295 \\
\text { Poultry workers } \\
\text { from sites with } \\
\text { suspected or } \\
\text { confirmed } \\
\text { H5N1-affected } \\
\text { poultry (farm } \\
\text { workers, market } \\
\text { workers, cullers), } \\
\text { vets from poultry } \\
\text { veterinary clinics, } \\
\text { laboratory } \\
\text { workers from the } \\
\text { National } \\
\text { Veterinary } \\
\text { Research Institute } \\
\text { Nigeria, } \\
\text { Mar-Apr } 2006\end{array}$ & $\begin{array}{l}\text { Human } \\
\text { A/New York/55/2005 } \\
\text { (H3N2) } \\
\text { Avian } \\
\text { A/chicken/ } \\
\text { Nigeria/246/06 } \\
\text { (H5N1) } \\
\text { A/chicken/ } \\
\text { Nigeria/42/2006 } \\
\text { (H5N1) }\end{array}$ & $\begin{array}{l}\text { MN assay (positive if titres } \\
\geq 1: 80 \text { ) with confirmatory HI } \\
\text { assay (horse RBC) } \\
\text { No significant associations } \\
\text { for use of PPE or hand } \\
\text { washing among poultry } \\
\text { workers } \\
\text { No positive samples found } \\
\text { in study population for } \\
\text { H5N1, but } 97 \% \text { had } \\
\text { neutralizing titres } \geq 1: 80 \\
\text { against circulating human } \\
\text { H3N2 }\end{array}$ & III & $\begin{array}{l}\text { Fair } \\
\text { Confirmation of } \\
\text { H5N1 infection } \\
\text { in poultry was } \\
\text { limited; } \\
\text { Convenience } \\
\text { sample with } \\
\text { some effort } \\
\text { made to find } \\
\text { absent or ill } \\
\text { employees }\end{array}$ \\
\hline Pawar SD $(2012)^{57}$ & $\begin{array}{l}\text { Descriptive } \\
\text { seroprevalence } \\
\text { survey }\end{array}$ & $\begin{array}{l}N_{\text {workers }}=338 \\
N_{\text {control samples }}=249 \\
\text { Workers from } \\
\text { poultry shops and } \\
\text { farms; Sera from } \\
\text { general } \\
\text { population used } \\
\text { to establish } \\
\text { baseline antibody } \\
\text { levels } \\
\text { India, } \\
\text { Jul-Dec } 2010\end{array}$ & $\begin{array}{l}\text { Avian } \\
\text { A/chicken/India/ } \\
\text { NIV/99321/09 } \\
\text { (H9N2) }\end{array}$ & $\begin{array}{l}\text { HI assay (turkey RBC), MN } \\
\text { assay; Assay results } \\
\text { reported for } \geq 40, \geq 80 \text { and } \\
\geq 160 \text { cut-offs } \\
\text { No positive samples in } \\
\text { baseline sera at } \geq 40 \text { cut-off } \\
21 / 338 \text { ( } 6.2 \% \text { ) were positive } \\
\text { by HI or } \mathrm{MN} \text { using } \geq 40 \\
\text { cut-off } \\
4 \text { people by HI and } 5 \\
\text { people from MN were } \\
\text { positive at } \geq 80 \text { cut-off; and } \\
2 \text { people and } 1 \text { person } \\
\text { were positive at } \geq 160 \text { by HI } \\
\text { and MN respectively }\end{array}$ & III & Good \\
\hline
\end{tabular}




\begin{tabular}{|c|c|c|c|c|c|c|}
\hline \multicolumn{7}{|c|}{ INDIVIDUALS WITH OCCUPATIONAL EXPOSURE TO AVIAN POPULATIONS } \\
\hline Study & Study Design & Participants & Influenza type & Key findings & Level & Quality \\
\hline Puzelli S $(2005)^{58}$ & $\begin{array}{l}\text { Descriptive } \\
\text { serological } \\
\text { survey }\end{array}$ & $\begin{array}{l}N_{\text {serum samples }}=983 \\
\text { Workers in several } \\
\text { categories of } \\
\text { labour in farms } \\
\text { Italy, 1999-2003 }\end{array}$ & $\begin{array}{l}\text { Avian } \\
\text { H7N1 } \\
\text { H7N3 }\end{array}$ & $\begin{array}{l}\mathrm{HI} \text { assay (horse } \mathrm{RBC} \text { ) and } \\
\text { MN assay, with Western } \\
\text { blot or hemagglutinin } \\
\text { assay for positive } \\
\text { confirmation }\end{array}$ & III & \\
\hline Santhia K (2009) ${ }^{59}$ & $\begin{array}{l}\text { Descriptive } \\
\text { household- } \\
\text { based cluster } \\
\text { seroprevalence } \\
\text { survey }\end{array}$ & $\begin{array}{l}\mathrm{N}=841 \\
\mathrm{n}_{\text {household }}=291 \\
\mathrm{n}_{\text {market vendors }}=87 \\
\text { Poultry rearing } \\
\text { households and } \\
\text { one live bird } \\
\text { market } \\
\text { Indonesia, } 2005\end{array}$ & $\begin{array}{l}\text { Avian } \\
\text { H5N1 }\end{array}$ & $\begin{array}{l}\text { HI assay used for poultry } \\
\text { (positive if titres } \geq 20 \text { ), MN } \\
\text { assay used for humans and } \\
\text { swine (positive if titres } \geq 80 \text { ) } \\
\text { Majority of households } \\
\text { had chickens and pigs, } \\
\text { chickens only, or chickens, } \\
\text { ducks and pigs } \\
\text { None of chickens or ducks } \\
\text { sampled were H5N1 } \\
\text { positive by RT-PCR; one } \\
\text { duck was positive for an } \\
\text { H4 influenza virus } \\
\text { None of the surveyed pigs } \\
\text { ( } \mathrm{n}=344 \text { ) were positive for } \\
\text { H5N1 by RT-PCR and MN } \\
\text { None of the household } \\
\text { participants were positive } \\
\text { for H5N1 by MN although } \\
57 \% \text { of participants were in } \\
\text { villages with a history of } \\
\text { H5N1 outbreaks }\end{array}$ & III & Fair \\
\hline
\end{tabular}




\begin{tabular}{|c|c|c|c|c|c|c|}
\hline \multicolumn{7}{|c|}{ INDIVIDUALS WITH OCCUPATIONAL EXPOSURE TO AVIAN POPULATIONS } \\
\hline Study & Study Design & Participants & Influenza type & Key findings & Level & Quality \\
\hline Schultsz C (2009) $)^{17}$ & $\begin{array}{l}\text { Descriptive } \\
\text { seroprevalence } \\
\text { survey }\end{array}$ & $\begin{array}{l}\mathrm{N}=500 \\
\mathrm{n}_{\text {worker }}=183 \\
\mathrm{n}_{\text {culler }}=317 \\
\text { Poultry workers } \\
\text { and cullers } \\
\text { Vietnam, 2004-05 }\end{array}$ & $\begin{array}{l}\text { Avian } \\
\text { H5N1 }\end{array}$ & $\begin{array}{l}\text { MN assay against } 2 \text { sets of } \\
\text { influenza strains with } \\
\text { positive samples (titres } \\
\geq 1: 80 \text { ) re-tested by HI } \\
\text { (horse RBC; positive if } \\
\text { titres } \geq 1: 80 \text { ); Cross- } \\
\text { reactivity with influenza A } \\
\text { viruses assessed (four fold } \\
\text { or greater reduction of H5 } \\
\text { titre in treated sera) } \\
\text { None of the workers } \\
\text { showed positive titre } \\
\text { against H5N1 } \\
\text { Small number of cullers } \\
\text { were positive in some MN } \\
\text { assays, but some samples } \\
\text { had suspected H1 } \\
\text { cross-reactivity } \\
3 \text { cullers presented with HI } \\
\text { titres of } 1: 20,1: 40 \text { and } \\
1: 200 ; \text { Involved in culling } \\
\text { for more than one year }\end{array}$ & III & Fair \\
\hline Shafir SC (2012) ${ }^{19}$ & $\begin{array}{l}\text { Descriptive } \\
\text { seroprevalence } \\
\text { survey }\end{array}$ & $\begin{array}{l}\mathrm{N}=401 \\
\text { Migratory bird } \\
\text { handlers } \\
\text { USA, 2008-10 }\end{array}$ & $\begin{array}{l}\text { Human } \\
\mathrm{pH} 1 \mathrm{~N} 1 \\
\text { Avian } \\
2008 \\
\mathrm{H} 5 \mathrm{~N} 2, \mathrm{H} 7 \mathrm{~N} 2, \mathrm{H} 9 \mathrm{~N} 2 \\
2009 \\
\mathrm{H} 5 \mathrm{~N} 2, \mathrm{H} 7 \mathrm{~N} 3 \\
2010 \\
\mathrm{H} 5 \mathrm{~N} 2, \mathrm{H} 7 \mathrm{~N} 2,\end{array}$ & $\begin{array}{l}\text { MN assay (positive if titres } \\
\geq 1: 40 \text { ) } \\
\text { Only one individual tested } \\
\text { positive for H5N2 } \\
\text { No evidence of AIV and } \\
\text { pH1N1 co-infection }\end{array}$ & III & Fair \\
\hline
\end{tabular}




\begin{tabular}{|c|c|c|c|c|c|c|}
\hline \multicolumn{7}{|c|}{ INDIVIDUALS WITH OCCUPATIONAL EXPOSURE TO AVIAN POPULATIONS } \\
\hline Study & Study Design & Participants & Influenza type & Key findings & Level & Quality \\
\hline Vong S $(2006)^{20}$ & $\begin{array}{l}\text { Descriptive } \\
\text { seroprevalence } \\
\text { survey }\end{array}$ & $\begin{array}{l}\mathrm{N}_{\text {households }}=93 \text { (351 } \\
\text { participants) } \\
\text { Rural village with } \\
\text { death due to } \\
\text { confirmed H5N1 } \\
\text { Cambodia, } 2005\end{array}$ & $\begin{array}{l}\text { Avian } \\
\text { H5N1 }\end{array}$ & $\begin{array}{l}\text { RT-PCR, MN assay } \\
\text { (positive if titre } \geq 80 \text { ) with } \\
\text { confirmatory Western blot } \\
\text { None of the participants } \\
\text { reported having febrile or } \\
\text { respiratory illness during } \\
\text { the affected period, and } \\
\text { none tested positive for } \\
\text { H5N1 despite regular, } \\
\text { high-intensity contact with } \\
\text { poultry or pigs in the } \\
\text { majority of the population } \\
\text { Slaughtering chickens } \\
\text { were not a significant risk } \\
\text { factor after controlling for } \\
\text { exposures found } \\
\text { significant in multivariate } \\
\text { analysis (e.g. cleaning up } \\
\text { cages/stalls, handling live } \\
\text { poultry, purchasing live } \\
\text { poultry, cleaning up } \\
\text { poultry feathers) }\end{array}$ & III & $\begin{array}{l}\text { Fair } \\
\text { Potential for } \\
\text { recall bias; } \\
\text { cannot assess } \\
\text { degree of } \\
\text { misclassification } \\
\text { without } \\
\text { confirmation of } \\
\text { H5N1 virus } \\
\text { infection in } \\
\text { poultry }\end{array}$ \\
\hline Wang M (2009) $)^{60}$ & $\begin{array}{l}\text { Descriptive } \\
\text { seroprevalence } \\
\text { survey }\end{array}$ & $\begin{array}{l}\mathrm{N}=2191 \\
\text { Healthy persons } \\
\text { from several } \\
\text { workplaces } \\
\text { (poultry retailers, } \\
\text { poultry } \\
\text { wholesalers, } \\
\text { workers in } \\
\text { large-scale } \\
\text { poultry-breeding } \\
\text { enterprise, } \\
\text { farmers in } \\
\text { small-scale rural } \\
\text { poultry farm, } \\
\text { workers in } \\
\text { pig-breeding } \\
\text { enterprise, } \\
\text { retailers of goods } \\
\text { other than poultry } \\
\text { in food market, } \\
\text { general } \\
\text { population) } \\
\text { China, Mar } \\
\text { 2007-Jul } 2008\end{array}$ & $\begin{array}{l}\text { Avian } \\
\text { H5N1 } \\
\text { H5N2 } \\
\text { H9N2 }\end{array}$ & $\begin{array}{l}\text { HI assay, MN assay; } \\
\text { Conditions for positive } \\
\text { titre not identified } \\
0.2 \% \text { and } 4.5 \% \text { prevalence } \\
\text { of anti-H5 and anti-H9 } \\
\text { antibodies, respectively, in } \\
\text { the study population } \\
\text { All anti-H5 positive } \\
\text { persons with poultry } \\
\text { retailers or wholesalers; } \\
\text { anti-H9 positive persons } \\
\text { found in all study groups } \\
\text { Positive rate in anti-H5 } \\
\text { lower than anti-H9 among } \\
\text { poultry retailers ( } 0.8 \% \text { vs. } \\
15.5 \%, \mathrm{p}<.001) \text { and } \\
\text { wholesalers (0.8\% vs. } 6.6 \% \text {, } \\
\text { p=.001) }\end{array}$ & III & Fair \\
\hline
\end{tabular}




\begin{tabular}{|c|c|c|c|c|c|c|}
\hline \multicolumn{7}{|c|}{ INDIVIDUALS WITH OCCUPATIONAL EXPOSURE TO AVIAN POPULATIONS } \\
\hline Study & Study Design & Participants & Influenza type & Key findings & Level & Quality \\
\hline Yamazaki Y (2009) ${ }^{61}$ & $\begin{array}{l}\text { Descriptive } \\
\text { seroprevalence } \\
\text { survey }\end{array}$ & $\begin{array}{l}\mathrm{N}=266 \\
\mathrm{n}_{\text {outbreak region }}=114 \\
\mathrm{n}_{\text {general pop }}=100 \\
\mathrm{n}_{\text {worker }}=52 \\
\text { General } \\
\text { inhabitants in } \\
\text { region where } \\
\text { H5N2 outbreak } \\
\text { occurred, general } \\
\text { population in } \\
\text { Japan, Employees } \\
\text { in or were in the } \\
\text { poultry industry } \\
\text { or related jobs } \\
\text { Japan, } \\
\text { May-Aug } 2006\end{array}$ & $\begin{array}{l}\text { Avian } \\
\mathrm{H} 5 \mathrm{~N} 2\end{array}$ & $\begin{array}{l}\text { MN assay (positive if titres } \\
\geq 1: 40 \text { ), } H \text { I assay (horse } \\
\text { RBC; positive if titres } \\
\geq 1: 40 \text { ) } \\
8 \text { samples from outbreak } \\
\text { region, } 4 \text { from general } \\
\text { population, } 8 \text { from poultry } \\
\text { workers showed MN titre } \\
\geq 40 \\
9 \text { samples from outbreak } \\
\text { region, } 2 \text { from general } \\
\text { population, } 2 \text { from poultry } \\
\text { workers showed HI titre } \\
\geq 40 \\
\text { Seropositivity was related } \\
\text { to age in poultry workers } \\
\text { (p=.038) } \\
\text { Positives in poultry workers } \\
\text { statistically significant } \\
\text { compared to general } \\
\text { population ( } p=.018 \text { ) }\end{array}$ & III & Good \\
\hline
\end{tabular}




\begin{tabular}{|c|c|c|c|c|c|c|}
\hline \multicolumn{7}{|c|}{ INDIVIDUALS WITH OCCUPATIONAL EXPOSURE TO SWINE POPULATIONS } \\
\hline Study & Study Design & Participants & Influenza type & Key findings & Level & Quality \\
\hline $\begin{array}{l}\text { Ayora-Talavera } \\
\text { G, }(2005)^{62}\end{array}$ & $\begin{array}{l}\text { Serological } \\
\text { testing } \\
\text { Convenience } \\
\text { sample (any } \\
\text { resident who } \\
\text { visited the } \\
\text { health service } \\
\text { for any medical } \\
\text { condition and } \\
\text { required } \\
\text { laboratory } \\
\text { rests) }\end{array}$ & $\begin{array}{l}\mathrm{N}=115 \\
\text { Indigenous } \\
\text { Mayan persons } \\
\text { from a rural } \\
\text { agricultural } \\
\text { community (pigs } \\
\text { roam freely in } \\
\text { town and in and } \\
\text { out of houses) } \\
\text { Mexico, } 2000\end{array}$ & $\begin{array}{l}\text { Human } \\
\text { A/Bayern/7/95 } \\
\text { (H1N1) } \\
\text { A/Sydney/5/97 } \\
\text { (H3N2) } \\
\text { Swine } \\
\text { A/Swine/Wisconsin/ } \\
\text { 238/97 (H1N1) } \\
\text { A/Swine/ } \\
\text { Minnesota/593/99 } \\
\text { (reassortant H3N2) }\end{array}$ & $\begin{array}{l}\mathrm{HI} \text { (chicken } \mathrm{RBC} \text {; positive } \\
\text { when titre } \geq 1: 40 \text { ) } \\
\text { Relative risk of being } \\
\text { seropositive from exposure to } \\
\text { pigs: } \\
\text { human } \mathrm{H} 1-1.93(1.2,3.0) \\
\text { human } \mathrm{H} 3-0.88(0.55,1.4) \\
\text { swine } \mathrm{H} 1-0.6(0.08,4.2) \\
\text { swine } \mathrm{H} 3-1.0(0.62,1.6) \\
\text { Reactivity rates were high to } \\
\mathrm{H} 3 \text { subtype influenza viruses, } \\
\text { and highest for } \mathrm{A} / \mathrm{Sw} / \\
\text { Minnesota }\end{array}$ & III & $\begin{array}{l}\text { Fair } \\
\text { Prevalence of } \\
\text { infection in } \\
\text { swine } \\
\text { unknown }\end{array}$ \\
\hline $\begin{array}{l}\text { Beaudoin A } \\
(2010)^{36}\end{array}$ & $\begin{array}{l}\text { Descriptive } \\
\text { survey with } \\
\text { serological } \\
\text { testing }\end{array}$ & $\begin{array}{l}\mathrm{N}=27 \\
\mathrm{n}_{\text {exposed }}=16 \\
\mathrm{n}_{\text {unexposed }}=9 \\
\text { Employees from } \\
\text { two large, } \\
\text { comparable } \\
\text { swine farms } \\
\text { (farm swine } \\
\text { influenza history } \\
\text { known); } \\
\text { Exposed } \\
\text { individuals were } \\
\text { those working } \\
\text { on the farm with } \\
\text { H2-positive pigs } \\
\text { Sep-Dec } 2006 \\
\text { USA, } 2008\end{array}$ & $\begin{array}{l}\text { Human } \\
\text { A/New Caledonia/ } \\
\text { 20/99 (H1N1) } \\
\text { A/Panama/2007/99 } \\
\text { (H3N2) } \\
\text { Swine } \\
\text { A/Sw/MO/4296424/ } \\
2006 \text { (H2N3) }\end{array}$ & $\begin{array}{l}\mathrm{HI} \text { (CDC protocol; positive if } \\
\text { titres } \geq 1: 40 \text {; assessed } \\
\text { cross-reactivity with } \mathrm{H} 1 \text { and } \mathrm{H} 3 \\
\text { human strains); MN (positive if } \\
\text { titres } \geq 1: 40 \text { ) } \\
\text { Four participants were H2N3 } \\
\text { positive (three born before } \\
\text { 1968, } 1 \text { birth year unknown), } \\
\text { with only one being part of } \\
\text { the exposed group (born in } \\
\text { 1949 and seropositivity may } \\
\text { be unrelated to recent } \\
\text { exposure) } \\
\text { All workers reported use of } \\
\text { some form of PPE (e.g. boots, } \\
\text { masks, gloves, protective } \\
\text { clothing), but not associated } \\
\text { with likelihood of } \\
\text { seropositivity }\end{array}$ & II-2 & $\begin{array}{l}\text { Good } \\
\text { Small } \\
\text { numbers; } \\
\text { History of } \\
\text { influenza } \\
\text { infection in } \\
\text { swine known }\end{array}$ \\
\hline $\begin{array}{l}\text { Gerloff NA } \\
(2011)^{26}\end{array}$ & $\begin{array}{l}\text { Serological } \\
\text { testing }\end{array}$ & $\begin{array}{l}\mathrm{N}=211 \\
\mathrm{~N}_{\text {control samples }}=224 \\
\text { Healthy } \\
\text { individuals with } \\
\text { past or present } \\
\text { professional } \\
\text { exposure to } \\
\text { swine; Serum } \\
\text { from the general } \\
\text { population } \\
\text { collected for } \\
\text { routine testing } \\
\text { used as control } \\
\text { Luxembourg, } \\
2009\end{array}$ & $\begin{array}{l}\text { Human } \\
\text { A/Luxembourg/ } \\
\text { 43/2009 (pH1N1) } \\
\text { A/Luxembourg/572/ } \\
2008 \text { (Seasonal H1N1) } \\
\text { Swine } \\
\text { A/Swine/Belgium/1/98 } \\
\text { (avian-like H1N1 SIV) }\end{array}$ & $\begin{array}{l}\text { MN (WHO protocol; screening } \\
\text { from } \geq 1: 10 \text { ) } \\
\text { GMTs significantly higher for } \\
\text { swine workers than controls } \\
\text { for pandemic virus } \\
\text { GMTs higher among swine } \\
\text { workers than controls for SIV, } \\
\text { but not statistically different } \\
\text { Being SIV positive increased } \\
\text { OR of being positive for } \\
\text { pH1N1 by 2.4 (1.3, 4.3) for } \\
\text { swine workers; OR increased } \\
\text { by } 6 \text { (2.9, 12.6) in controls } \\
\text { GMTs for seasonal influenza } \\
\text { significantly higher for swine } \\
\text { workers than controls }\end{array}$ & III & Good \\
\hline
\end{tabular}




\begin{tabular}{|c|c|c|c|c|c|c|}
\hline \multicolumn{7}{|c|}{ INDIVIDUALS WITH OCCUPATIONAL EXPOSURE TO SWINE POPULATIONS } \\
\hline Study & Study Design & Participants & Influenza type & Key findings & Level & Quality \\
\hline Gray GC $(2007)^{63}$ & $\begin{array}{l}\text { Prospective } \\
\text { study with } \\
\text { serological } \\
\text { testing }\end{array}$ & $\begin{array}{l}\mathrm{N}=803 \\
\mathrm{n}_{\text {AHS swine }} \\
\text { exposed } \\
\mathrm{n}_{\text {AHS non-swine }} \\
\text { exposed } \\
\mathrm{n}_{\text {uni controls }}=70 \\
\text { Swine workers } \\
\text { from the } \\
\text { Agricultural } \\
\text { Health Study } \\
\text { cohort; spouses } \\
\text { and university } \\
\text { participants } \\
\text { used as controls } \\
\text { USA, 2004-2006 }\end{array}$ & $\begin{array}{l}\text { Human } \\
\text { A/New Caledonia/ } \\
\text { 20/99 (H1N1) } \\
\text { A/Panama/2007/ } \\
99 \text { (H3N2) } \\
\text { Swine } \\
\text { A/swine/WI/238/ } \\
97 \text { (H1N1) } \\
\text { A/swine/WI/R33F/2011 } \\
\text { (H1N2) }\end{array}$ & $\begin{array}{l}\text { HI (CDC protocol, guinea pig } \\
\text { RBC used for human strains } \\
\text { and turkey RBC used for swine } \\
\text { strains; positive at titres } \geq 1: 40 \\
\text { considered initially, but } \\
\text { spectrum also evaluated) } \\
\text { >90\% AHS swine-exposed } \\
\text { individuals have worked with } \\
\text { swine for >10 years } \\
\text { At enrollment: } \\
\text { Swine-exposed had higher } \\
\text { titres against swine influenza } \\
\text { subtypes of H1N1 than other } \\
\text { groups } \\
\text { Compared to university } \\
\text { controls, swine-exposed had } \\
\text { increased risk for swine H1N1 } \\
\text { adjusted OR } 54.9 \text { (13.0, } 232.6 \text { ); } \\
\text { non-swine exposed had } \\
\text { adjusted OR of } 28.2 \text { (6.1, } \\
\text { 130.1) } \\
\text { Serological activity against } \\
\text { swine influenza was observed } \\
\text { during follow-up period with } \\
\text { relatively few cases of } \\
\text { self-reported ILI } \\
\text { A/lowa/CEID23/05 isolated } \\
\text { from one individual with } \\
\text { symptoms }\end{array}$ & II-2 & $\begin{array}{l}\text { Poor } \\
\text { Voluntary } \\
\text { participation; } \\
\text { Age a } \\
\text { statistically } \\
\text { significant } \\
\text { factor in } \\
\text { analysis, and } \\
\text { there is a } \\
\text { difference in } \\
\text { average age } \\
\text { between } \\
\text { university } \\
\text { controls and } \\
\text { other } \\
\text { participants }\end{array}$ \\
\hline
\end{tabular}




\begin{tabular}{|c|c|c|c|c|c|c|}
\hline \multicolumn{7}{|c|}{ INDIVIDUALS WITH OCCUPATIONAL EXPOSURE TO SWINE POPULATIONS } \\
\hline Study & Study Design & Participants & Influenza type & Key findings & Level & Quality \\
\hline $\begin{array}{l}\text { Kitikoon P } \\
(2011)^{64}\end{array}$ & $\begin{array}{l}\text { Serology } \\
\text { testing }\end{array}$ & $\begin{array}{l}\mathrm{N}=243 \\
\mathrm{n}_{\text {exposed }}=78 \\
\mathrm{n}_{\text {control }}=60 \\
\mathrm{n}_{\text {swine }}=85 \\
\text { Farm workers } \\
\text { from two } \\
\text { commercial } \\
\text { farms; Non- } \\
\text { exposed } \\
\text { controls } \\
\text { recruited } \\
\text { voluntarily from } \\
\text { Blood Centre } \\
\text { and hospital; } \\
\text { Swine } \\
\text { Thailand, } \\
\text { 2008/09 }\end{array}$ & $\begin{array}{l}\text { Human } \\
\text { A/Thailand/CU41/06 } \\
\text { (seasonal H1N1) } \\
\text { A/Nonthaburi/102/09 } \\
\text { (pH1N1) } \\
\text { Swine } \\
\text { A/Swine/Thailand/ } \\
\text { CU-CB1/06 (H1N1) } \\
\text { A/Swine/Thailand/ } \\
\text { Cu-CHK4/09 (H1N2) }\end{array}$ & $\begin{array}{l}\text { HI (chicken RBC for swH1N1, } \\
\text { swH1N2, huH1N1; turkey RBC } \\
\text { for pH1N1; titres } \geq 40 \\
\text { considered exposed) } \\
50 \text { and } 92 \% \text { of workers from } \\
\text { the two farms had antibodies } \\
\text { against SIV circulating on the } \\
\text { farm (individuals included farm } \\
\text { owners, pig handlers, } \\
\text { veterinarians, farm cleaners } \\
\text { and office workers) } \\
\text { Compared to control group, } \\
\text { exposed workers had OR } \\
42.63 \text { (14.65, 124) for elevated } \\
\text { antibodies to SIV H1N1 and } \\
\text { OR } 58 \text { (13.12, 256.3) to SIV } \\
\text { H1N2 } \\
\text { Pigs from all age groups on } \\
\text { both farms were seropositive } \\
\text { to both swine strains; no } \\
\text { antibodies detected against } \\
\text { human strains }\end{array}$ & III & $\begin{array}{l}\text { Fair } \\
\text { Volunteer } \\
\text { controls may } \\
\text { not represent } \\
\text { baseline in the } \\
\text { general } \\
\text { population }\end{array}$ \\
\hline
\end{tabular}




\begin{tabular}{|c|c|c|c|c|c|c|}
\hline \multicolumn{7}{|c|}{ INDIVIDUALS WITH OCCUPATIONAL EXPOSURE TO SWINE POPULATIONS } \\
\hline Study & Study Design & Participants & Influenza type & Key findings & Level & Quality \\
\hline $\begin{array}{l}\text { Krumbholz A } \\
(2010)^{65}\end{array}$ & $\begin{array}{l}\text { Prospective } \\
\text { study with } \\
\text { serological } \\
\text { testing }\end{array}$ & $\begin{array}{l}\mathrm{N}=236 \\
\mathrm{n}_{\text {slaughterers/ }} \\
\text { inspectors } \\
\mathrm{n}_{\text {farmers }}=46 \\
\mathrm{n}_{\text {vet }}=22 \\
\mathrm{n}_{\text {control }}=118 \\
\text { Professionals } \\
\text { with } \\
\text { occupational } \\
\text { exposure to } \\
\text { pigs; Non- } \\
\text { exposed } \\
\text { controls were } \\
\text { blood-donors } \\
\text { frequency } \\
\text { matched by } \\
\text { gender and age } \\
\text { Germany, Dec } \\
\text { 2007-Apr } 2009\end{array}$ & $\begin{array}{l}\text { Nine human and swine } \\
\text { strains }\end{array}$ & 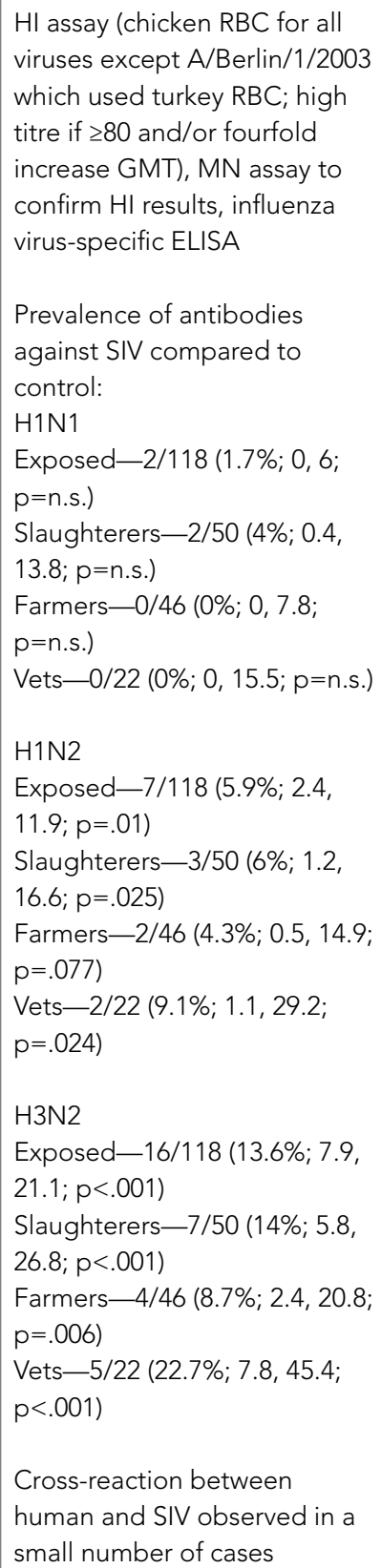 & $\|-2$ & Good \\
\hline
\end{tabular}




\begin{tabular}{|c|c|c|c|c|c|c|}
\hline \multicolumn{7}{|c|}{ INDIVIDUALS WITH OCCUPATIONAL EXPOSURE TO SWINE POPULATIONS } \\
\hline Study & Study Design & Participants & Influenza type & Key findings & Level & Quality \\
\hline $\begin{array}{l}\text { Lopez-Robles G } \\
(2012)^{66}\end{array}$ & $\begin{array}{l}\text { Cross-sectional } \\
\text { with serological } \\
\text { testing }\end{array}$ & $\begin{array}{l}\mathrm{N}=125 \\
\mathrm{n}_{\text {exposed }}=62 \\
\mathrm{n}_{\text {control }}=63 \\
\text { Swine workers } \\
\text { from } 15 \text { swine } \\
\text { commercial } \\
\text { farms; Controls } \\
\text { from activities } \\
\text { unrelated to } \\
\text { swine industry } \\
\text { Mexico, 2007/08 }\end{array}$ & $\begin{array}{l}\text { Human } \\
\text { A/New Caledonia/ } \\
\text { 20/99 (H1N1) } \\
\text { A/Panama/2001/ } \\
\text { 99-like (H3N2) } \\
\text { Swine } \\
\text { A/Swine/ } \\
\text { England/163266/87 } \\
\text { (human lineage } \\
\text { segments H3N2) } \\
\text { A/Swine/Wisconsin/ } \\
\text { 238/97 (H1N1) }\end{array}$ & $\begin{array}{l}\text { RT-PCR, } \mathrm{HI} \text { assay (seropositive } \\
\text { with titres } \geq 1: 32 \text { ) } \\
\text { Serological evidence of } \\
\text { previous exposure to swine } \\
\text { and human influenza detected } \\
\text { Exposed had greater } \\
\text { seroprevalence for SIV , but } \\
\text { lower seroprevalence for } \\
\text { human influenza than control } \\
\text { group } \\
\text { 1/62 exposed individuals had } \\
\text { both swine and human } \mathrm{H} 1 \mathrm{~N} 1 \text {; } \\
5 / 62 \text { had both swine and } \\
\text { human } \mathrm{H} 3 \mathrm{~N} 2 \\
1 \text { control had swine } \mathrm{H} 3 \mathrm{~N} 2 \\
\text { antibodies } \\
\text { History of influenza } \\
\text { vaccination protective against } \\
\text { swine } \mathrm{H} 3 \mathrm{~N} 2 \text { (OR=0.05; } 0.01 \text {, } \\
0.52 ; \mathrm{p}<.05 \text { ) }\end{array}$ & III & $\begin{array}{l}\text { Fair } \\
\text { Unexposed } \\
\text { were not } \\
\text { randomly } \\
\text { selected, is } \\
\text { subject to } \\
\text { selection bias, } \\
\text { and may not } \\
\text { be } \\
\text { representative } \\
\text { of the general } \\
\text { population }\end{array}$ \\
\hline
\end{tabular}




\begin{tabular}{|c|c|c|c|c|c|c|}
\hline \multicolumn{7}{|c|}{ INDIVIDUALS WITH OCCUPATIONAL EXPOSURE TO SWINE POPULATIONS } \\
\hline Study & Study Design & Participants & Influenza type & Key findings & Level & Quality \\
\hline $\begin{array}{l}\text { Myers KP } \\
(2006)^{67}\end{array}$ & $\begin{array}{l}\text { Cross-sectional } \\
\text { seroprevalence }\end{array}$ & $\begin{array}{l}\mathrm{N}=352 \\
\mathrm{n}_{\text {farmers }}=111 \\
\mathrm{n}_{\text {processors }}=97 \\
\mathrm{n}_{\text {vets }}=65 \\
\mathrm{n}_{\text {control }}=79 \\
\text { Swine-exposed } \\
\text { (farmers, meat } \\
\text { processing } \\
\text { workers, vets/vet } \\
\text { techs); Control } \\
\text { group from } \\
\text { university } \\
\text { volunteers } \\
\text { without } \\
\text { occupational } \\
\text { exposure to } \\
\text { swine } \\
\text { USA, 2002-2004 }\end{array}$ & $\begin{array}{l}\text { Human } \\
\text { A/New Caledonia/ } \\
\text { 20/99 (H1N1) } \\
\text { A/Panama/2007/99 } \\
\text { (H3N2) } \\
\text { A/Nanchang/933/95 } \\
\text { (H3N2) } \\
\text { Swine } \\
\text { A/Swine/WI/238/97 } \\
\text { (H1N1) } \\
\text { A/Swine/WI/R33F/01 } \\
\text { (H1N2) } \\
\text { A/Swine/Minnesota/ } \\
\text { 593/99 (H3N2) }\end{array}$ & 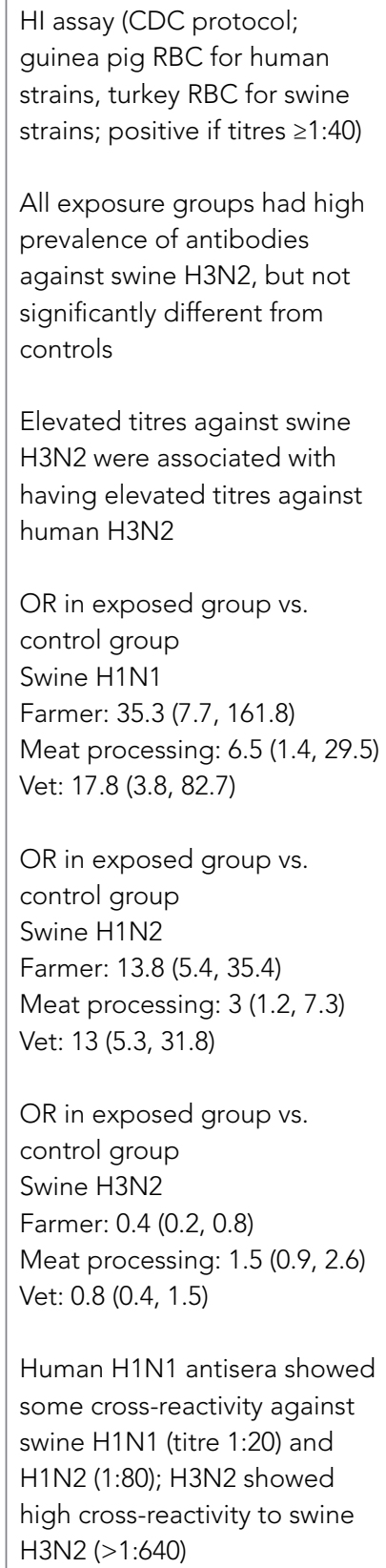 & III & $\begin{array}{l}\text { Fair } \\
\text { Control group } \\
\text { voluntary and } \\
\text { may not } \\
\text { represent the } \\
\text { general } \\
\text { population } \\
\text { and is not } \\
\text { similar to the } \\
\text { exposed } \\
\text { group by age } \\
\text { and sex }\end{array}$ \\
\hline
\end{tabular}




\begin{tabular}{|c|c|c|c|c|c|c|}
\hline \multicolumn{7}{|c|}{ INDIVIDUALS WITH OCCUPATIONAL EXPOSURE TO SWINE POPULATIONS } \\
\hline Study & Study Design & Participants & Influenza type & Key findings & Level & Quality \\
\hline $\begin{array}{l}\text { Olsen CW } \\
(2002)^{68}\end{array}$ & $\begin{array}{l}\text { Survey with } \\
\text { serological } \\
\text { testing }\end{array}$ & $\begin{array}{l}\mathrm{N}=76 \\
\mathrm{~N}_{\text {control samples }}=114 \\
\text { Farmers, farm } \\
\text { employees, } \\
\text { spouses and } \\
\text { children, farm } \\
\text { vets; Control } \\
\text { serum samples } \\
\text { from urban } \\
\text { residents } \\
\text { USA, Sep } \\
\text { 96-Apr } 97\end{array}$ & $\begin{array}{l}\text { Human } \\
\text { A/Johannesburg/ } \\
\text { 82/96 (H1N1) } \\
\text { A/Nanchang/ } \\
\text { 933/95 (H3N2) } \\
\text { Swine } \\
\text { A/Swine/Indiana/ } \\
\text { 1726/88 (H1N1) } \\
\text { A/Nebraska/01/92 } \\
\text { (zoonotic human } \\
\text { isolate of swine H1N1) }\end{array}$ & $\begin{array}{l}\text { HI assay (chicken RBC; } \\
\text { fourfold titre rises, titres } \geq 40 \\
\text { and } \geq 80 \text { analyzed further) } \\
\text { No cross-reactivity detected } \\
\text { between human and swine } \\
\text { strains } \\
\text { Preseason serum samples } \\
\text { from } 17 / 74 \text { farm participants } \\
\text { were seropositive to either } \\
\text { swine virus (15/17 were } \\
\text { seropositive to both) vs. } 1 / 114 \\
\text { among controls, p<.001 } \\
\text { GMTs to human viruses were } \\
\text { not significantly different from } \\
\text { control group } \\
\text { 3/74 farm participants had } \\
\text { four-fold titre increases to } \\
\text { either swine virus } \\
\text { Factors associated with } \\
\text { seropositivity to swine virus: } \\
\text { being a farm owner, being } \\
\text { part of a farm family, being } \\
\geq 50 \text { years of age }\end{array}$ & III & $\begin{array}{l}\text { Fair } \\
\text { Exposure for } \\
\text { urban controls } \\
\text { unknown } \\
\text { because they } \\
\text { were obtained } \\
\text { from a serum } \\
\text { bank }\end{array}$ \\
\hline $\begin{array}{l}\text { Olsen CW } \\
(2006)^{69}\end{array}$ & Case report & $\begin{array}{l}\mathrm{n}=1 \\
\text { Farm worker } \\
\text { Canada, } 2005\end{array}$ & $\begin{array}{l}\text { Triple reassortant } \\
\text { A/Ontario/RV1273/05 }\end{array}$ & $\begin{array}{l}\text { Virus detected during } \\
\text { diagnostic workup in worker, } \\
\text { but unclear if he had been } \\
\text { actively infected } \\
\text { Several other influenza A } \\
\text { viruses were isolated from } \\
\text { swine across Canada (MB, AB, } \\
\text { BC, ON), and turkeys } \\
\text { Human, swine and turkey } \\
\text { viruses found to descend from } \\
\text { a single lineage of viruses; } \\
\text { also share a human/classical } \\
\text { swine/avian triple reassortant } \\
\text { genotype with the H3N2 virus } \\
\text { detected in swine in the USA } \\
\text { in } 1998\end{array}$ & III & Good \\
\hline
\end{tabular}




\begin{tabular}{|c|c|c|c|c|c|c|}
\hline \multicolumn{7}{|c|}{ INDIVIDUALS WITH OCCUPATIONAL EXPOSURE TO SWINE POPULATIONS } \\
\hline Study & Study Design & Participants & Influenza type & Key findings & Level & Quality \\
\hline $\begin{array}{l}\text { Ramirez A } \\
(2006)^{70}\end{array}$ & $\begin{array}{l}\text { Cross sectional } \\
\text { survey with } \\
\text { serological } \\
\text { testing }\end{array}$ & $\begin{array}{l}\mathrm{N}=128 \\
\mathrm{n}_{\text {exposed }}=49 \\
\mathrm{n}_{\text {control }}=79 \\
\text { Individuals who } \\
\text { had worked in a } \\
\text { swine } \\
\text { confinement } \\
\text { facility within the } \\
\text { past } 12 \text { months; } \\
\text { Controls } \\
\text { selected from a } \\
\text { concurrent study } \\
\text { at a university } \\
\text { Majority of } \\
\text { exposed were } \\
\text { males, whereas } \\
\text { majority of } \\
\text { controls were } \\
\text { female } \\
\text { USA, 2004/05 }\end{array}$ & N/A & $\begin{array}{l}\text { HI assay (guinea pig RBC for } \\
\text { human strains, turkey RBC for } \\
\text { swine strains; outcomes } \\
\text { grouped into titres }<10 \text { and } \\
>10 \text { ) } \\
\text { Workers who sometimes or } \\
\text { never wore gloves were more } \\
\text { likely to have elevated titres } \\
(\mathrm{HI}>10) \text { compared to controls } \\
\text { (OR: } 30.3 ; 3.8,243.5) \text {, and other } \\
\text { workers who wore gloves most } \\
\text { of the time or always (OR: } \\
\text { 12.7; } 1.1,151.1 \text { ) }\end{array}$ & III & Fair \\
\hline $\begin{array}{l}\text { Robinson JL } \\
(2007)^{71}\end{array}$ & $\begin{array}{l}\text { Survey with } \\
\text { serological } \\
\text { testing }\end{array}$ & $\begin{array}{l}\mathrm{N}=54 \\
\text { Members of a } \\
\text { communal farm } \\
\text { where an infant } \\
\text { was hospitalized } \\
\text { with a swine- } \\
\text { related influenza } \\
\text { virus } \\
\text { Canada, } 2006\end{array}$ & $\begin{array}{l}\text { Human } \\
\text { A/New } \\
\text { Caledonia/20/99 } \\
\text { (H1N1) } \\
\text { A/Wisconsin/67/2005 } \\
\text { (H3N2) } \\
\text { Swine } \\
\text { A/Ontario/ } \\
\text { RV1273/2005 (swine } \\
\text { H3N2) } \\
\text { A/Canada/1158/2006 } \\
\text { (detected in infant) }\end{array}$ & $\begin{array}{l}\text { HI assay (guinea pig RBC; } \\
\text { positive at titre } \geq 32 \text { ), RT-PCR } \\
8 \text { other members from } 3 \\
\text { households were seropositive } \\
\text { (HI } \geq 32 \text { ) (4 from household of } \\
\text { index patient) } \\
\text { Most had no swine exposure } \\
\text { or had < } 1 \text { h/week of swine } \\
\text { exposure } \\
\text { Nasal swabs from } 25 \text { grower } \\
\text { pigs were negative for SIV } \\
\text { 4/10 swine serum samples } \\
\text { were positive for H3N2 with } 1 \\
\text { sample being seropositive for } \\
\text { A/Canada/1158/2006 }\end{array}$ & III & Good \\
\hline
\end{tabular}




\begin{tabular}{|c|c|c|c|c|c|c|}
\hline \multicolumn{7}{|c|}{ INDIVIDUALS WITH OCCUPATIONAL EXPOSURE TO SWINE POPULATIONS } \\
\hline Study & Study Design & Participants & Influenza type & Key findings & Level & Quality \\
\hline $\begin{array}{l}\text { Terebuh P } \\
(2010)^{72}\end{array}$ & $\begin{array}{l}\text { Prospective } \\
\text { cohort (Swine } \\
\text { and human } \\
\text { surveillance } \\
\text { with serological } \\
\text { testing) }\end{array}$ & $\begin{array}{l}\mathrm{n}_{Y 1 \text { workers }}=88 \\
\text { (85\% of initial } \\
\text { enrollment) } \\
\mathrm{n}_{\text {Y2 workers }}=76 \\
\text { (78\% of initial } \\
\text { enrollment) } \\
2 \text { age-matched } \\
\text { (within 5y) } \\
\text { controls per } \\
\text { worker; } 210 \\
\text { control samples } \\
\text { in y1, } 202 \\
\text { samples in y2 } \\
\text { Workers } \\
\text { from a swine } \\
\text { production } \\
\text { facility; Controls } \\
\text { from two urban } \\
\text { centres } \\
\text { USA, Sep-May } \\
2002-2004\end{array}$ & $\begin{array}{l}9 \text { influenza strains } \\
\text { (human, swine, triple } \\
\text { reassortment) }\end{array}$ & $\begin{array}{l}\text { HI assay (positive at titre } \\
\geq 1: 40 \text { ); Paired sera collected at } \\
\text { beginning and end of study, } \\
\text { additional serum sample } \\
\text { collected from vaccinated } \\
\text { workers } 2 \text { weeks after } \\
\text { vaccination } \\
\text { Majority of workers had } \\
\text { worked with pigs for } 5+\text { yrs } \\
\text { Year } 1 \\
15 / 42 \text { positive responses from } \\
\text { workers met ILI definition, but } \\
\text { none positive for influenza by } \\
\text { culture } \\
111 \text { swine reported to have } \\
\text { displayed ILI signs } \\
52 \text { (59\%) seropositive to at } \\
\text { least one human virus and } 46 \\
\text { (52\%) seropositive to at least } \\
\text { one swine virus } \\
10 \text { workers seroconverted to } \\
\text { one or more SIVs; } 8 \\
\text { seroconverted between the } \\
\text { pre- and post-vaccination } \\
\text { sample, the remaining } 2 \text { did } \\
\text { not receive vaccine (titre rise } \\
\text { from 5-20) } \\
\text { Seropositivity to SIV } \\
\text { associated with receiving } \\
\text { seasonal influenza vaccine } \\
\text { ( } p<.05 \text { ) in year } 1 \text { only }\end{array}$ & II-2 & $\begin{array}{l}\text { Good } \\
\text { Study periods } \\
\text { were aligned } \\
\text { with human } \\
\text { influenza } \\
\text { season with no } \\
\text { monitoring } \\
\text { over the } \\
\text { summer } \\
\text { although } \\
\text { swine } \\
\text { outbreaks still } \\
\text { occurred }\end{array}$ \\
\hline
\end{tabular}




\begin{tabular}{|c|c|c|c|c|c|c|}
\hline \multicolumn{7}{|c|}{ INDIVIDUALS WITH OCCUPATIONAL EXPOSURE TO SWINE POPULATIONS } \\
\hline Study & Study Design & Participants & Influenza type & Key findings & Level & Quality \\
\hline & & & & $\begin{array}{l}\text { Year } 2 \\
11 / 32 \text { positive responses from } \\
\text { workers met ILI definition; one } \\
\text { tested positive for influenza } \\
111 \text { swine reported to have } \\
\text { displayed ILI signs } \\
55 \text { (72\%) seropositive to at } \\
\text { least one human virus and } \\
47 \text { (62\%) seropositive to at } \\
\text { least one swine virus } \\
29 \text { workers seroconverted to } \\
\text { one or more SIVs } \\
\text { Swine influenza vaccine } \\
\text { needlestick injury occurred in } \\
4 \text { (4\%) and } 11 \text { (14\%) workers in } \\
\text { year } 1 \text { and year } 2 \text { respectively } \\
\text { Worker GMTs for three SIVs } \\
\text { were significantly higher than } \\
\text { controls ( } p<.0001 \text { ) } \\
20 \text { outbreaks identified in } \\
\text { swine, } 17 \text { were positive for } \\
\text { influenza A by RT-PCR }\end{array}$ & & \\
\hline
\end{tabular}




\section{LEVELS OF EVIDENCE BASED ON RESEARCH DESIGN}

\begin{tabular}{l|l}
\hline I & Evidence from randomized controlled trial(s). \\
\hline II-1 & Evidence from controlled trial(s) without randomization. \\
\hline II-2 & $\begin{array}{l}\text { Evidence from cohort or case-control analytic studies, preferably from more than one centre or research group using clinical } \\
\text { outcome measures of vaccine efficacy. }\end{array}$ \\
\hline II-3 & $\begin{array}{l}\text { Evidence obtained from multiple time series with or without the intervention. Dramatic results in uncontrolled experiments } \\
\text { (such as the results of the introduction of penicillin treatment in the 1940s) could also be regarded as this type of evidence. }\end{array}$ \\
\hline III & $\begin{array}{l}\text { Opinions of respected authorities, based on clinical experience, descriptive studies and case reports, or reports of } \\
\text { expert committees. }\end{array}$ \\
\hline
\end{tabular}

\section{QUALITY (INTERNAL VALIDITY) RATING OF EVIDENCE}

\begin{tabular}{l|l}
\hline Good & A study (including meta-analyses or systematic reviews) that meets all design- specific criteria* well. \\
\hline Fair & $\begin{array}{l}\text { A study (including meta-analyses or systematic reviews) that does not meet (or it is not clear that it meets) at least one } \\
\text { design-specific criterion* but has no known "fatal flaw". }\end{array}$ \\
\hline Poor & $\begin{array}{l}\text { A study (including meta-analyses or systematic reviews) that has at least one design-specific* "fatal flaw", or an accumulation } \\
\text { of lesser flaws to the extent that the results of the study are not deemed able to inform recommendations. }\end{array}$
\end{tabular}

* General design specific criteria are outlined in Harris et al., 2001.73 


\section{Appendix B: National seasonal influenza vaccination recommendations for workers occupationally exposed to animals}

\begin{tabular}{|c|c|c|c|}
\hline Country & Organization & Recommendation & Reference \\
\hline \multirow[t]{2}{*}{ Canada } & $\begin{array}{l}\text { Public Health Agency } \\
\text { of Canada-National } \\
\text { Advisory Committee } \\
\text { on Immunization } \\
\text { (PHAC-NACl) }\end{array}$ & $\begin{array}{l}\text { People in direct contact during culling operations } \\
\text { involving poultry infected with avian influenza } \\
\text { Direct involvement may be defined as sufficient contact } \\
\text { with infected poultry to allow transmission of avian virus } \\
\text { to the exposed person. The relevant individuals include } \\
\text { those performing the cull, as well as others who may be } \\
\text { directly exposed to the avian virus, such as supervising } \\
\text { veterinarians and inspectors. }\end{array}$ & $\begin{array}{l}\text { An Advisory Committee Statement } \\
\text { (ACS). National Advisory } \\
\text { Committee on Immunization } \\
\text { (NACl): Statement on Seasonal } \\
\text { Influenza Vaccine for 2011-2012 }\end{array}$ \\
\hline & $\begin{array}{l}\text { Canadian Food Inspection } \\
\text { Agency (CFIA) }\end{array}$ & $\begin{array}{l}\text { Vaccination for those involved in the food production } \\
\text { system for biosecurity. } \\
\text { (CFIA uses the NACl statement that all healthy Canadians } \\
\text { get the seasonal vaccine as the rationale for producers } \\
\text { and their families, farm workers, veterinarians, farm service } \\
\text { personnel (including feed truck drivers and vaccination } \\
\text { and insemination crews), and other people visiting swine } \\
\text { operations to get seasonal vaccine.) }\end{array}$ & $\begin{array}{l}\text { CFIA website on Animal Biosecurity } \\
\text { ww.inspection.gc.ca/english/anima/ } \\
\text { biosec/20111207inde.shtml }\end{array}$ \\
\hline Australia & $\begin{array}{l}\text { National Health } \\
\text { and Medical Research } \\
\text { Council, Department of } \\
\text { Health and Ageing }\end{array}$ & $\begin{array}{l}\text { People involved in the commercial poultry industry or in } \\
\text { culling poultry during confirmed avian influenza activity. } \\
\text { Vaccination using the current influenza season vaccine } \\
\text { composition is recommended for poultry workers and } \\
\text { others in regular close contact with poultry during an } \\
\text { avian influenza outbreak. Although routine influenza } \\
\text { vaccine does not protect against avian influenza, there is } \\
\text { a possibility that a person who was infected at the same } \\
\text { time with avian and human strains of influenza virus could } \\
\text { allow reassortment of the } 2 \text { strains to form a virulent } \\
\text { strain that could spread from human to human (ie. } \\
\text { initiate a pandemic). }\end{array}$ & $\begin{array}{l}\text { Australian Immunisation Handbook } \\
9^{\text {th }} \text { ed. (Last updated } 26 \text { March, 2008) } \\
\text { www.immunise.health.gov.au/ } \\
\text { internet/immunise/publishing.nsf/ } \\
\text { Content/Handbook-influenza } \\
\text { (This recommendation is not made } \\
\text { in the } 2012 \text { seasonal influenza } \\
\text { statement produced by the } \\
\text { Australian Technical Advisory } \\
\text { Group on Immunisation, although } \\
\text { they are authors of the } \\
\text { immunisation handbook.) }\end{array}$ \\
\hline Hong Kong & $\begin{array}{l}\text { Centre for Health } \\
\text { Protection, Department of } \\
\text { Health-Scientific } \\
\text { Committee on Vaccine } \\
\text { Preventable Diseases }\end{array}$ & $\begin{array}{l}\text { Poultry Workers: Seasonal influenza vaccination is } \\
\text { recommended for poultry workers and persons involved } \\
\text { in slaughtering of animals potentially infected with } \\
\text { highly pathogenic avian influenza virus for minimizing } \\
\text { the risk of re-assortment and eventual emergence of a } \\
\text { novel influenza virus with pandemic potential through } \\
\text { preventing concomitant infections by the human influenza } \\
\text { and avian influenza viruses in humans. } \\
\text { Pig Farmers and Pig-slaughtering Industry Personnel: } \\
\text { Pig farmers and pig-slaughtering industry personnel are } \\
\text { recommended to receive seasonal influenza vaccine to } \\
\text { prevent emergence of new influenza A virus in either } \\
\text { human or pig hosts. }\end{array}$ & $\begin{array}{l}\text { Recommendations on Seasonal } \\
\text { Influenza vaccination for the } \\
2011 / 12 \text { Season } \\
\text { www.chp.gov.hk/files/pdf/ } \\
\text { recommendations_on_seasonal_ } \\
\text { influenza_vaccination_for_ } \\
\text { the_201112_season.pdf }\end{array}$ \\
\hline
\end{tabular}




\begin{tabular}{|c|c|c|c|}
\hline Country & Organization & Recommendation & Reference \\
\hline $\begin{array}{l}\text { United } \\
\text { Kingdom }\end{array}$ & $\begin{array}{l}\text { Joint Council on } \\
\text { Vaccination and } \\
\text { Immunisation (JCVI) }\end{array}$ & $\begin{array}{l}\text { An annual influenza vaccination program for poultry } \\
\text { workers was introduced in the 2006/07 season as } \\
\text { recommended by the Advisory Committee on Dangerous } \\
\text { Pathogens (ACDP). This was reviewed in } 2010 \text { where JCVI } \\
\text { noted that the implementation of the program was } \\
\text { difficult and vaccine uptake in this population was low. } \\
\text { Since avian influenza occurred infrequently in the UK and } \\
\text { Europe, the risk of reassortment events would be very low. } \\
\text { JCVI advised that there was no benefit in continuing } \\
\text { routine influenza vaccination in poultry workers beyond } \\
\text { the } 2010 / 11 \text { season. } \\
\text { ACDP advised JCVI in } 2006 \text { and } 2009 \text { that there was no } \\
\text { need to offer pig workers seasonal influenza vaccination } \\
\text { as a precautionary public health measure because of } \\
\text { limited evidence showing the role of pigs in transmitting } \\
\text { influenza to humans. The risk of reassortment of swine } \\
\text { and human influenza viruses was also considered low by } \\
\text { the ACDP. }\end{array}$ & $\begin{array}{l}\text { Joint Committee on Vaccination } \\
\text { and Immunisation: Draft minutes. } \\
\text { 6 October } 2010 \\
\text { www.dh.gov.uk/prod_consum_dh/ } \\
\text { groups/dh_digitalassets/@dh/@ } \\
\text { ab/documents/digitalasset/ } \\
\text { dh_124596.pdf } \\
\text { 17 June 2009 } \\
\text { www.dh.gov.uk/prod_consum_dh/ } \\
\text { groups/dh_digitalassets/@dh/@ } \\
\text { ab/documents/digitalasset/ } \\
\text { dh_116040.pdf }\end{array}$ \\
\hline \multirow[t]{2}{*}{$\begin{array}{l}\text { United } \\
\text { States }\end{array}$} & \multirow[t]{2}{*}{$\begin{array}{l}\text { Centers for Disease } \\
\text { Control and Prevention- } \\
\text { Advisory Committee on } \\
\text { Immunization Practices } \\
\text { (CDC_ACIP) }\end{array}$} & $\begin{array}{l}\text { CDC has recommended that persons who are charged } \\
\text { with responding to avian influenza among poultry receive } \\
\text { seasonal influenza vaccination. }\end{array}$ & $\begin{array}{l}\text { Prevention and control of influenza } \\
\text { with vaccines. Recommendations } \\
\text { of the Advisory Committee on } \\
\text { Immunization Practices (ACIP), } \\
2010 \text {. }\end{array}$ \\
\hline & & $\begin{array}{l}\text {...influenza vaccination of swine workers-regardless of } \\
\text { whether or not they have a high risk condition-is } \\
\text { important to reduce the risk of transmitting seasonal } \\
\text { influenza viruses from ill people to pigs. Seasonal } \\
\text { influenza vaccination of workers might also decrease the } \\
\text { potential for people or pigs to become co-infected with } \\
\text { both human and swine influenza viruses. Such dual } \\
\text { infections could result in genetic reassortment of the two } \\
\text { different influenza A viruses and lead to a new influenza } \\
\text { A virus that has a different combination of genes, and } \\
\text { which could pose significant public health concern. }\end{array}$ & $\begin{array}{l}\text { CDC Interim guidance for workers } \\
\text { who are employed at commercial } \\
\text { swine farms: Preventing the spread } \\
\text { of influenza A viruses } \\
\text { www.cdc.gov/flu/swineflu/ } \\
\text { guidance-commercial-pigs.htm }\end{array}$ \\
\hline Germany & $\begin{array}{l}\text { German Committee for } \\
\text { Biological Agents }\end{array}$ & $\begin{array}{l}\text {...Since } 2003 \text {, the German Committee for biological } \\
\text { agents has recommended seasonal influenza vaccination } \\
\text { for people exposed to } A / H 5 N 1 \text { infected birds or poultry. }\end{array}$ & 11 \\
\hline
\end{tabular}

